Review

\title{
Beyond Typical Electrolytes for Energy Dense Batteries
}

\section{Rana Mohtadi}

Materials Research Department, Toyota Research Institute of North America, Ann Arbor, MI 48105, USA; rana.mohtadi@toyota.com; Tel.: +1-734-995-4012

Academic Editors: Ewa C.E. Rönnebro and Gulaim A. Seisenbaeva

Received: 17 December 2019; Accepted: 31 March 2020; Published: 14 April 2020

\begin{abstract}
The ever-rising demands for energy dense electrochemical storage systems have been driving interests in beyond Li-ion batteries such as those based on lithium and magnesium metals. These high energy density batteries suffer from several challenges, several of which stem from the flammability/volatility of the electrolytes and/or instability of the electrolytes with either the negative, positive electrode or both. Recently, hydride-based electrolytes have been paving the way towards overcoming these issues. Namely, highly performing solid-state electrolytes have been reported and several key challenges in multivalent batteries were overcome. In this review, the classes of hydride-based electrolytes reported for energy dense batteries are discussed. Future perspectives are presented to guide research directions in this field.
\end{abstract}

Keywords: electrolyte; hydride; battery

\section{Introduction}

Over the past few decades, nickel-metal hydride and later lithium-ion batteries, have been thrusted to the forefront of societal electrification owing to their energy density and reliable performances. For instance, the relatively high specific energy densities of Li-ion batteries ( $c a$ at least 2 times that in nickel-metal hydride) and higher specific power have positioned them to play an increasingly important role in driving technologies encompassing miniature and portable devices (i.e., cell phones, laptops), medium scale (plug-in hybrid PHEV and electric vehicles EVs) up to large scale stationary and grid applications [1].However, recently there have been increasing demands for highly performing batteries beyond those based on typical Li-ion [2]. In particular, the energy and power densities that can be offered by Li-ion batteries are insufficient to meet those needs. This has been fueling R\&D efforts towards battery chemistries capable of meeting these requirements that include solid-state batteries and those based on high capacity metals such as $\mathrm{Li}$ and $\mathrm{Mg}$. For example, in contrast to batteries utilizing liquid electrolytes, the use of solid-state electrolytes allows for efficient bipolar stacking design of batteries that decreases the dead space between single cells thereby increasing the overall energy density whilst eliminating the use of volatile liquid electrolytes [3,4]. In addition, the high hardness of solid electrolytes was suggested to mitigate the occurrence of Li dendrites that form upon Li metal battery charge/discharge. On the other hand, batteries that use multivalent metals have been promising a high energy density option that uses benign and earth abundant metals such as $\mathrm{Mg}$ (volumetric storage capacity is $3832 \mathrm{mAh} / \mathrm{cm}^{3}$ vs. $2061 \mathrm{mAh} / \mathrm{cm}^{3}$ for Li metal) and eliminates safety hazards encountered with Li metal.

Enabling batteries beyond Li-ion mandates the presence of highly performing battery core components (anode, cathode, electrolyte) capable of supporting competitive battery performances. Electrolytes, which are the media that connect the positive (cathode) and negative (anode) electrodes, are positioned to play a critical role in enabling these technologies. However, whilst numerous families of materials have been proposed for these batteries, they fall short of simultaneously meeting the challenging technological needs. For example, highly conducting $\mathrm{Li}^{+}$solid-state electrolytes 
such as sulfides suffer from limitations in their electrochemical stability window [3,5]. In addition, electrolytes used in multivalent batteries had severe limitations caused by their reliance on complex chloro-reagents or were altogether incapable of supporting highly efficient performances $[2,6,7]$ Therefore, there have been dedicated efforts that target the development of new materials positioned to overcome these challenges.

The past decade has witnessed unexpected and rapid developments of hydrides-type materials as competent solid and liquid electrolytes poised to offer potential solutions [8]. This review explains how these advancements came to fruition, summarizes the classes of hydride-based electrolytes and highlights key advancements made thus far.

\section{Explanation of the Review's Structure}

The development of practical electrolytes for energy storage devices is a very challenging endeavor as they are required to meet a myriad of requirements (Figure 1) [9]. All of these demands are based on a battery cell design that allows for optimized battery performances and offer a commercially viable energy storage system. For example, high conductivity is required to enable acceptable battery discharge/charge rate capabilities; wide electrochemical window is needed to prevent electrolyte decomposition that can result in battery failure (i.e., electrolyte is compatible with battery electrodes); absence of no-self discharge or electronically insulating electrolyte is required to prevent battery capacity loss whilst low/non-volatility is highly desired to minimize safety risks and lower manufacturing costs. This review explains how hydride electrolytes for mono and multivalent batteries have been shown to meet several of these requirements which included the demonstration of high conductivity, wide electrochemical window and non/low volatility.

Hydrides are materials characterized by the presence of a hydrogen atom bound with many elements forming ionic (i.e., negatively charged $\mathrm{H}^{-}$or protonic $\mathrm{H}^{+}$form), covalent, or interstitial systems [8]. In particular, those constituting of anions formed by $\mathrm{H}^{-}$covalently bonding to a metal such as boron have been attracting tremendous attention over the past few years as battery electrolytes. The high potential of hydrides as electrolytes was first reported in the borohydride salts and was manifested by two key accomplishments [8]: (1) The discovery of high $\mathrm{Li}^{+}$ion conductivity ( $c$ a $10^{-3} \mathrm{~S} / \mathrm{cm}$ at $423 \mathrm{~K}$ ) and wide electrochemical window (5V) in the solid state (discussed in Section 3) and (2) The design of boron-hydrogen $\mathrm{Mg}$ battery liquid electrolytes that are highly compatible with the passivation prone $\mathrm{Mg}$ metal (>90\% Mg deposition/stripping efficiency) (discussed in Section 4). A timeline depicting key developments is captured in Figure 1b.

The research of hydrides as solid-state electrolytes for monovalent batteries has been motivated by improving the room temperature conductivities of $\mathrm{Li}^{+}$and $\mathrm{Na}^{+}$ions (Section 3). High room temperature conductivities in the order of $10^{-3} \mathrm{~S} / \mathrm{cm}$, which placed hydride solid-state electrolytes amongst the best-known electrolytes, was the culmination of these efforts. These studies are discussed in Section 3.1, which is dedicated to strongly hydridic salts, and Section 3.2, which discusses electrolyte salts with a weak hydridic nature. Section 4 explains the advancements made in the field of hydrides as electrolytes for multivalent batteries wherein higher than $99 \% \mathrm{Mg}$ deposition/stripping coulombic efficiency ( $>90 \%$ for Ca deposition/stripping), coupled with a wide electrochemical stability window exceeding $5 \mathrm{~V}$ for $\mathrm{Mg}$ salts, resulted in major breakthroughs in this field. Section 4.1 discusses the research of hydride as liquid electrolytes for $\mathrm{Mg}$ and $\mathrm{Ca}$ batteries that was driven by enabling a high compatibility with these metals. These studies unveiled the limitations of liquid electrolytes employing salts with a highly hydritic nature as was manifested by the low anodic stability of the borohydride salts (i.e., $<2 \mathrm{~V}$ vs. $\mathrm{Mg} / \mathrm{Mg}^{2+}$ ). Section 4.2 discusses the design concepts that improved the anodic stability of hydrides whilst maintaining the compatibility with $\mathrm{Mg}$ metal accomplished using closo-borate salts. The findings reported in Sections 4.1 and 4.2 most recently paved the way for important $\mathrm{Mg}$ metal-hydride fundamental interfacial studies (Section 4.3) and the design of solid-state Mg electrolytes (Section 4.4). Section 5 discusses a very recent new application of hydrides as non-volatile and highly stable battery solvents (ionic liquids), which are amongst the best known ionic liquid electrolytes due to their wide electrochemical window $(>4 \mathrm{~V})$ and 
compatibility with both monovalent and multivalent metals. Finally, Section 6 showcases key battery demonstrations of hydrides as electrolytes in mono and multivalent batteries.

a

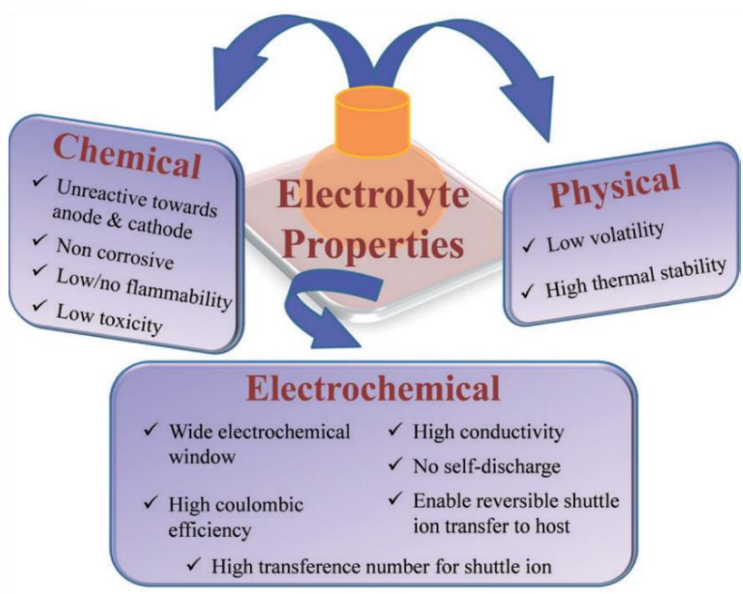

b

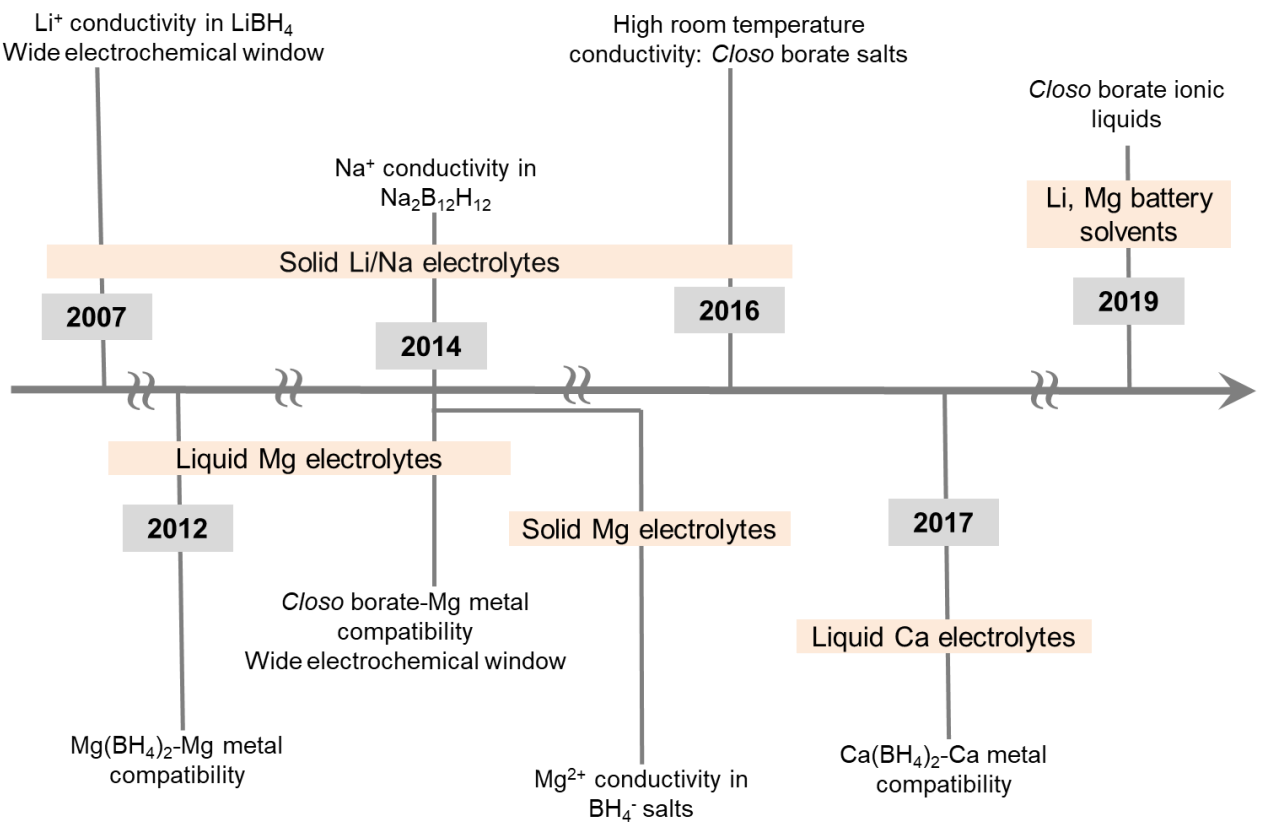

Figure 1. (a) Key properties required for competent battery electrolytes. Reprinted with permission from reference [9], copyright 2014 WILEY-VCH. (b) Timeline depicting key advancements made in the development of hydrides as battery electrolytes.

\section{Solid-State Hydride Electrolytes for Monovalent Batteries}

The observation of appreciable conductivity at room temperature in a hydride was first reported close to four decades ago in $\mathrm{Li}_{2} \mathrm{NH}\left(\mathrm{ca} 10^{-4} \mathrm{~S} / \mathrm{cm}, \mathrm{ca} 10^{-2} \mathrm{~S} / \mathrm{cm}\right.$ at $400 \mathrm{~K}$ ) [10]. The ionic conduction was mediated by Frenkel pair defects and/or charged vacancies and the cation diffusion occurred via pathways, which involved octahedral to tetrahedral jumps along the (001) crystallographic direction. However, its poor electrochemical stability $\left(0.7 \mathrm{~V}\right.$ vs. $\left.\mathrm{Li}^{+} / \mathrm{Li}\right)$ and high reactivity made it less attractive amongst other solid-state electrolytes researched at that time. This interest in the solid-state cationic conductivity in hydrides was revived from 2007 with the unexpected discovery of high $\mathrm{Li}^{+}$mobility after microwave hearting of $\mathrm{LiBH}_{4}$ [11]. This salt has been known to undergo phase transition from 
orthohombic to hexagonal phases at $380 \mathrm{~K}$ [12], however, the mobility of $\mathrm{Li}^{+}$was revealed from permittivity measurements that demonstrated the presence of conductive heat loss in the hexagonal phase which suggested $\mathrm{Li}^{+}$ion mobility (hydrogen is immobile as it is covalently bonded in $\mathrm{BH}_{4}{ }^{-}$). Electrochemical impedance measurements (Figure 2) further confirmed the presence of high $\mathrm{Li}^{+}$conductivity in the hexagonal high temperature phase (in the order of $10^{-3} \mathrm{~S} / \mathrm{cm}$ ). In this phase, the high mobility of $\mathrm{Li}^{+}$ions was explained by the presence of rotational disorder in the $\mathrm{BH}_{4}{ }^{-}$, the formation of metastable interstitial sites and the alignment of both the $\mathrm{Li}^{+}$and $\mathrm{BH}_{4}{ }^{-}$along the $a$ and $b$ axes thereby permitting unobstructed migration of $\mathrm{Li}^{+}$in both directions [13-15]. The salt was shown to have high oxidative stability beyond $5 \mathrm{~V}$ vs. $\mathrm{Li}^{+} / \mathrm{Li}$, however this stability was later shown to be apparent and not representative of the thermodynamic stability of this salt. For example, the anodic stability was measured to be about $2 \mathrm{~V}$ vs. $\mathrm{Li} / \mathrm{Li}^{+}$, when large surface area carbon was infused within the electrolyte [16]. The seminal discovery of $\mathrm{Li}^{+}$high mobility in the solid state triggered research interests to investigate hydrides as solid-state electrolytes for $\mathrm{Li}^{+}$and $\mathrm{Na}^{+}$ion batteries. These are described in the next Sub-Sections.
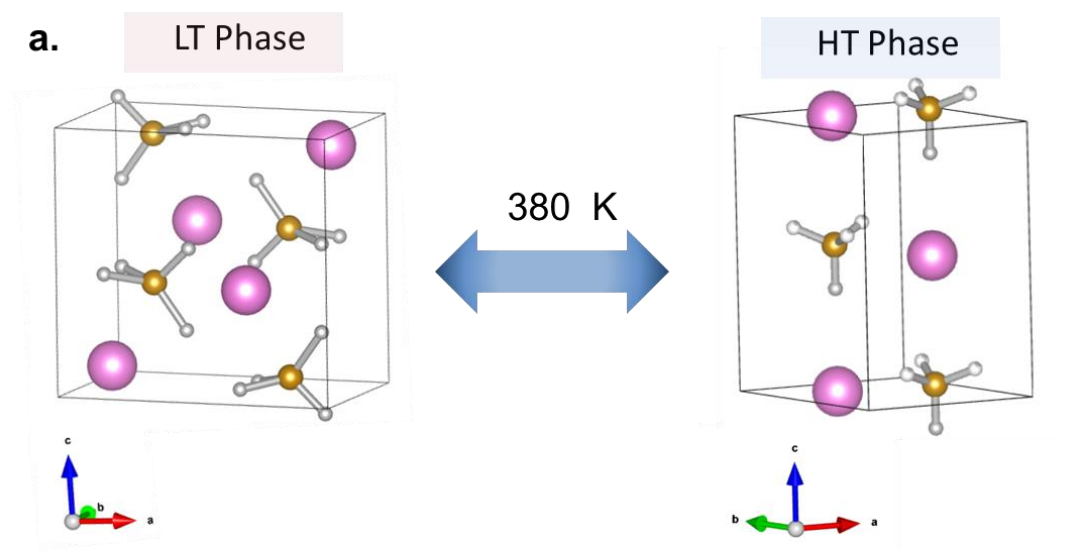

b.

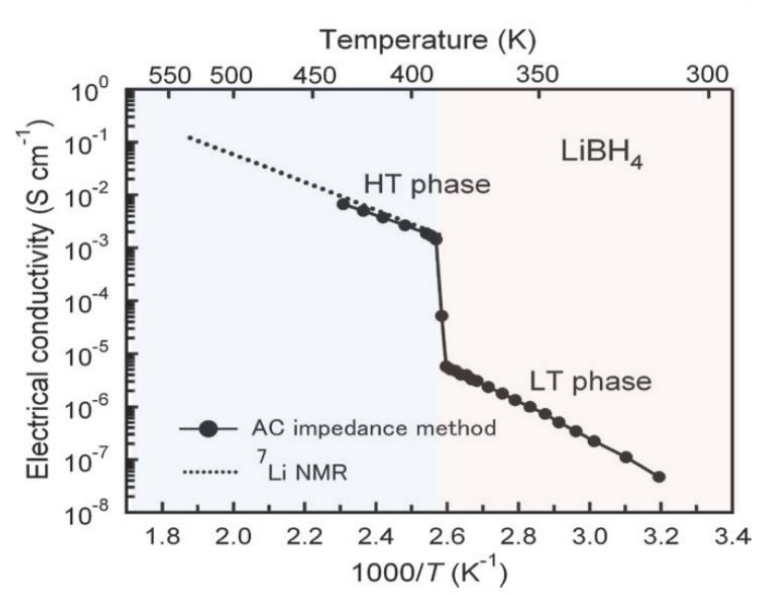

c.
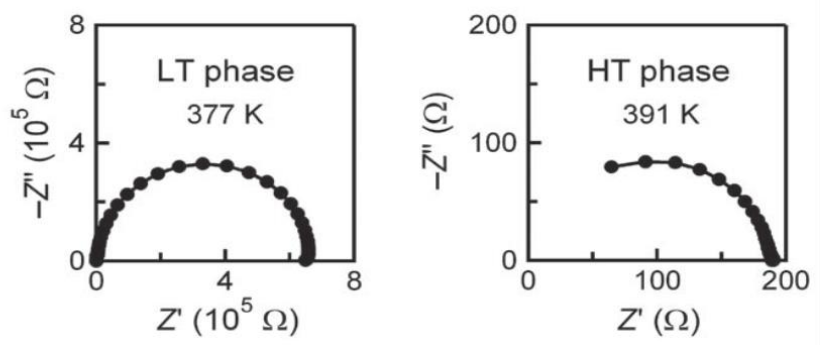

Figure 2. Properties of solid-state electrolytes for Li batteries: (a) Phase transition in $\mathrm{LiBH}_{4}$, (b) Arrhenius plot depicting the ionic conductivity of $\mathrm{LiBH}_{4},(\mathrm{c})$ Impedance spectra of the low and high temperature $\mathrm{LiBH}_{4}$ phases. Panels $\mathbf{b}$ and $\mathbf{c}$ are reproduced with permission from reference [11], American Institute of Physics. 


\subsection{Development of Highly Conductive Solid Electrolytes}

In an effort to lower the phase transition temperature of $\mathrm{LiBH}_{4}$ to a superconductor, i.e., enable high conductivity at room temperature, the concept of stabilizing the hexagonal phase through the use of halide dopants $\left(\mathrm{Br}^{-}, \mathrm{Cl}^{-}\right.$and $\left.\mathrm{I}^{-}\right)$, used to partially substitute the $\mathrm{BH}_{4}^{-}$anion through forming solid solutions, was conceived and investigated [17-19]. This approach was proven most successful for $(1-x) \operatorname{Li}\left(\mathrm{BH}_{4}\right)+x$ LiI solid solution, where a hexagonal crystal at room temperature $(x>13 \%)$ could be formed using mechanochemical synthesis and demonstrated high $\mathrm{Li}^{+}$conductivities, i.e., $0.1 \times 10^{-3} \mathrm{~S} / \mathrm{cm}$ at $303 \mathrm{~K}$ for the solid solution with $40 \% \mathrm{LiI}$.

Beyond the aforementioned concept, other studies increased the room temperature ionic conductivities through the formation of mixed borohydride-amide salts as was shown for $\mathrm{Li}^{+}$in trigonal $\mathrm{Li}_{2}\left(\mathrm{BH}_{4}\right)\left(\mathrm{NH}_{2}\right)$ and cubic $\mathrm{Li}_{4}\left(\mathrm{BH}_{4}\right)\left(\mathrm{NH}_{2}\right)_{3}$ where high conductivities in the order of $10^{-4} \mathrm{~S} / \mathrm{cm}$ were achieved at room temperature [20]. The key for enabling these high conductivities was attributed to the presence of multiple $\mathrm{Li}^{+}$crystallographic sites [20]. Interestingly, the activation energy for $\mathrm{Li}_{4}\left(\mathrm{BH}_{4}\right)\left(\mathrm{NH}_{2}\right)_{3}(0.26 \mathrm{eV})$ was lower than the hexagonal superconductor $\mathrm{LiBH}_{4}$ phase $(0.53 \mathrm{eV})[13,20]$. It is worth noting that $\mathrm{Li}_{2}\left(\mathrm{BH}_{4}\right)\left(\mathrm{NH}_{2}\right)$ became a molten salt at a relatively low temperature (onset $c a$ $350 \mathrm{~K})$. Further increase of the $\mathrm{LiBH}_{4} / \mathrm{LiNH}_{2}$ to $1: 2$ resulted in high conductivities $\left(6.4 \times 10^{-3} \mathrm{~S} / \mathrm{cm}\right.$ at $313 \mathrm{~K}$ ) through the formation of cubic $\mathrm{Li}_{3}\left(\mathrm{BH}_{4}\right)\left(\mathrm{NH}_{2}\right)_{2}$ phase (isostructural to $\left.\mathrm{Li}_{4}\left(\mathrm{BH}_{4}\right)\left(\mathrm{NH}_{2}\right)_{3}\right)$ [21]. This salt underwent partial melting at $313 \mathrm{~K}$, so it would be insightful to determine the contribution of the liquid phase to the overall bulk conductivity.

Other borohydride salts studied that increased the conductivity of $\mathrm{Li}^{+}$included mixed-cation mixed-anion borohydrides [22,23]. In particular, in $\mathrm{LiM}\left(\mathrm{BH}_{4}\right)_{3} \mathrm{Cl}(\mathrm{M}=$ cation), the disordered distribution of $\mathrm{Li}^{+}$increased the ionic conductivity at $293 \mathrm{~K}$ to $1.02 \times 10^{-4}, 3.5 \times 10^{-4}, 2.3 \times 10^{-4} \mathrm{~S} / \mathrm{cm}$ for $\mathrm{Ce}, \mathrm{Gd}$ and La-containing compounds, respectively. In addition, bimetallic borohydride oxide [24] i.e., $\mathrm{LiCa}_{3}\left(\mathrm{BH}_{4}\right)\left(\mathrm{BO}_{3}\right)_{2}$ had a $\mathrm{Li}^{+}$conductivity of $2.5 \times 10^{-6} \mathrm{~S} / \mathrm{cm}$ at room temperature which increased by about an order of magnitude when prepared with excess lithium and doped with either heterovalent $\mathrm{Na}^{+}$or homovalent $\mathrm{Sr}^{2+}$ (conductivities in the order of $10^{-5} \mathrm{~S} / \mathrm{cm}$ at room temperature) [25]. A structural investigation of $\mathrm{LiCa}_{3}\left(\mathrm{BH}_{4}\right)\left(\mathrm{BO}_{3}\right)_{2}$ showed that the borohydride was not directly involved in the conduction mechanism as (calcium borohydride substructure served to stabilize the percolating pathway) the conduction paths were composed exclusively of $\mathrm{BO}_{3}{ }^{3-}$ anions, which formed faced connected tetra- and octahedra accessible sites for $\mathrm{Li}^{+}$jumps and suggested the vacancy-dependent mobility of $\mathrm{Li}^{+}$.

Alternate approaches that sought to increase the conductivity of $\mathrm{LiBH}_{4}$ utilized composites which included those with nano oxides or sulfides. In the former case, high room temperature conductivity $\left(10^{-4} \mathrm{~S} / \mathrm{cm}\right)$ was observed for the $\mathrm{LiBH}_{4}-\mathrm{SiO}_{2}$ nanocomposite prepared by melt infiltration of the borohydride into a mesoporous inorganic silica scaffold (Figure 3) [26,27]. The study suggested that the high mobility of $\mathrm{Li}^{+}$was not related to stabilization of the hexagonal phase but was presumably caused by the high density of defects and low diffusion barriers at the interface between the two solids, which resulted from disorder, strain and space-charge regions [27,28]. Follow up studies demonstrated a similar effect using $\mathrm{Al}_{2} \mathrm{O}_{3}$ [29] and $\mathrm{C}_{60}$ [30] additives (note that the electronic conductivity in the $\mathrm{C}_{60}$ [30] composites could be higher than that desired from a solid electrolyte). The formation of composites with sulfides was first reported for $\mathrm{LiBH}_{4}: \mathrm{P}_{2} \mathrm{~S}_{5}$, where the preparation process resulted in a material that went beyond a composite formation evident from a new crystalline $90 \mathrm{LiBH}_{4}: 10 \mathrm{P}_{2} \mathrm{~S}_{5}$ phase that exhibited a high conductivity in the order of $10^{-3} \mathrm{~S} \mathrm{~cm}^{-1}$ around $300 \mathrm{~K}$ [31]. The combination of $\mathrm{LiBH}_{4}$ with glassy sulfide glass electrolytes $x \mathrm{LiBH}_{4}-(100-x): 0.75 \mathrm{Li}_{2} \mathrm{~S}: 0.25 \mathrm{P}_{2} \mathrm{~S}_{5}$ [32] using ball milling resulted in improved conductivity (i.e., at $x=33$ it showed $1.6 \times 10^{-3} \mathrm{~S} / \mathrm{cm}$ ) and low activation energy $(0.30 \mathrm{eV})$. Interestingly, Raman spectroscopy suggested that $\mathrm{BH}_{4}{ }^{-}$was in the same state as that occurring in the hexagonal superconducting $\mathrm{LiBH}_{4}$ phase, where high rotational freedom and delocalized negative charge weakened the electrostatic interactions between $\mathrm{Li}^{+}$and $\mathrm{BH}_{4}{ }^{-}$. The extension of composite studies to $\mathrm{Li}\left(\mathrm{BH}_{4}\right)_{3} \mathrm{I}$ resulted in similar improvements [33]. Other composites that yielded varying degrees of conductivity improvements, albeit less than those achieved with the 
sulfides, included composites with other borohydrides as $\mathrm{Ca}\left(\mathrm{BH}_{4}\right)_{2}$ [34], $\mathrm{NaBH}_{4}$ [35], with hydrides such as $\mathrm{MgH}_{2}$ [36], or borohydride-hydride ternary mixtures [37], and mixtures with halides such as $\mathrm{NaCl}[38]$.

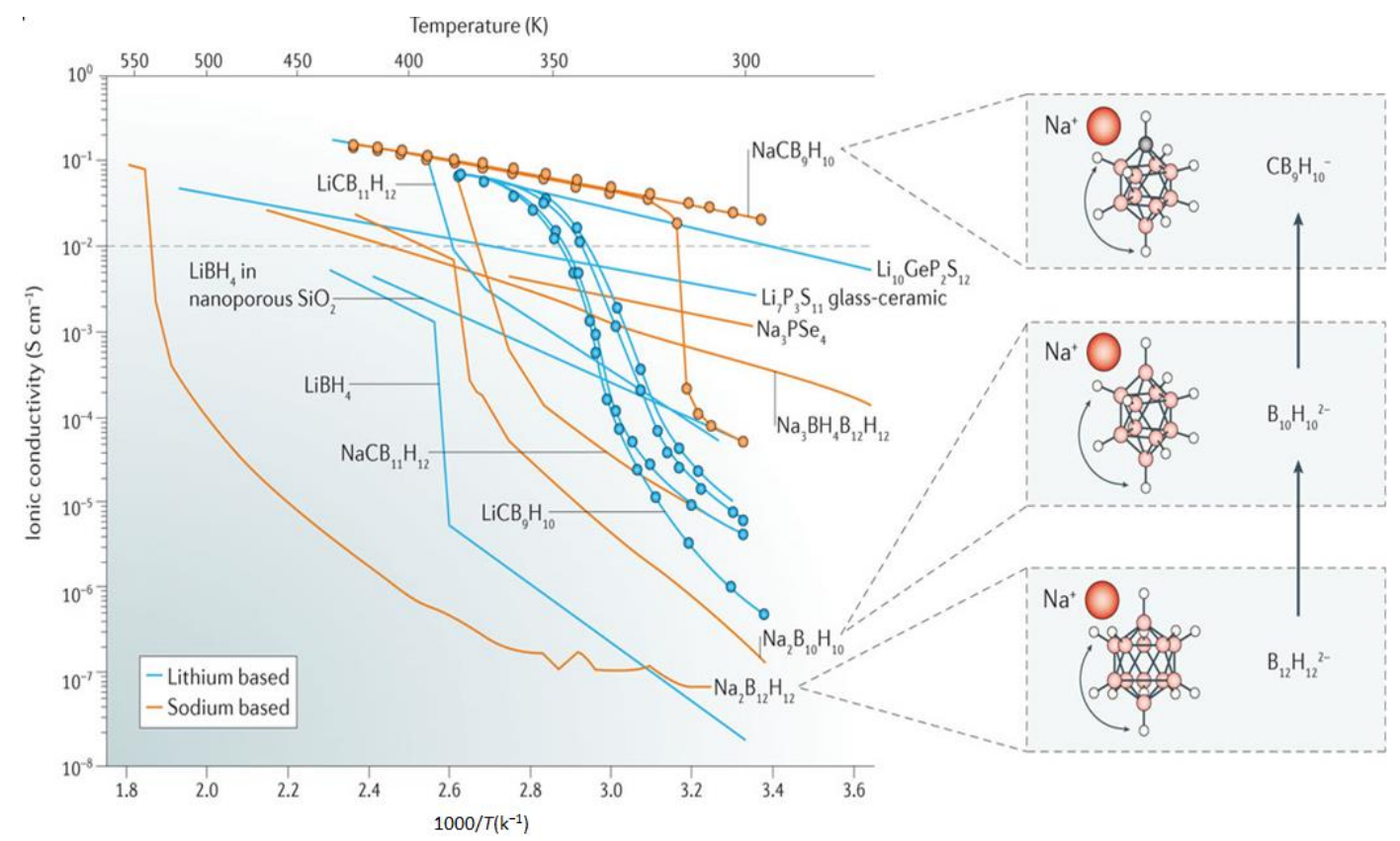

Figure 3. Arrhenius plots depicting the cationic conductivity in a variety of hydrides. Reprinted with permission from reference. [8], copyright 2016 Macmillan Publishers Limited, part of Springer Nature.

Neutral molecules that are adducted to $\mathrm{LiBH}_{4}$ were also investigated to increase the room temperature conductivity, as was demonstrated for solid-state lithium borohydride ammoniates $\mathrm{Li}\left(\mathrm{NH}_{3}\right)_{\mathrm{x}} \mathrm{BH}_{4}, \mathrm{x}=0.5$ and 1.0 [39]. A dramatic change in the ionic conductivity was attributed to the formation of defects induced by the partial desorption of $\mathrm{NH}_{3}$. For example, for $\mathrm{Li}\left(\mathrm{NH}_{3}\right) \mathrm{BH}_{4}$, the conductivity increased from $1.5 \times 10^{-6} \mathrm{~S} / \mathrm{cm}$ at $303 \mathrm{~K}$ to $2.21 \times 10^{-3} \mathrm{~S} / \mathrm{cm}$ at temperatures $>313 \mathrm{~K}$. Note that a closed system is required for these electrolytes so that the equilibrium pressure of ammonia is achieved, otherwise, reformation of $\mathrm{LiBH}_{4}$ will occur. Detailed structural analyses are desired to establish the conduction mechanism in these salts.

Unlike the case for the lithium salts, the formation of borohydrides that are highly $\mathrm{Na}^{+}$conductive was less successful [40-42]. For example at room temperature, the conductivity of $\mathrm{Na}^{+}$in $\mathrm{NaBH}_{4}$, $\mathrm{NaNH}_{2}$, and $\mathrm{Na}_{3}\left(\mathrm{BH}_{4}\right)_{2} \mathrm{I}$ were in the range $10^{-10}-10^{-9} \mathrm{~S} / \mathrm{cm}$. Disordered distribution of $\mathrm{Na}^{+}$resulted in increased mobility, as was reported for $\mathrm{Na}_{2}\left(\mathrm{BH}_{4}\right)\left(\mathrm{NH}_{2}\right)$ (ca $10^{-6} \mathrm{~S} / \mathrm{cm}$ at $300 \mathrm{~K}$ ), however the conductivity remained inferior to that reported in the lithium salts $[40,41]$.

Inspired by the promising results in borohydrides, other complex hydrides such as alanates and amides were investigated [41,43]. In these cases, no transition to a super conducting phase was observed in the alanates leading to relatively low cationic mobilities [43]. Likewise, with the exception of $\mathrm{Li}_{2} \mathrm{NH}$, imides and amides were less successful in demonstrating a good potential as solid-state electrolytes [44-46].

\subsection{Towards Achieving High $\mathrm{Li}^{+}, \mathrm{Na}^{+}$Mobilities: Closo-Borates}

Investigations of ionic conduction mechanisms in borohydrides showed that it is not only vacancy-dependent but also based on the "paddle-wheel" mechanism [47-49] wherein the high rotational mobility of the $\left(\mathrm{M}_{\mathrm{y}} \mathrm{X}_{\mathrm{n}}\right)^{\delta-}$ units promotes the ionic conductivity and lowers the activation energy [50,51]. This concept inspired investigating boron clusters (closo-borates)-based salts as electrolytes. These are found as undesirable byproducts that form during the thermal dehydrogenation of borohydrides [52]. 
Namely, the structural evolution of $\mathrm{Li}_{2} \mathrm{~B}_{12} \mathrm{H}_{12}$ with temperature indicated possible $\mathrm{Li}^{+}$conduction following transformation at $638 \mathrm{~K}$ to a disordered phase ( $\beta$ phase) with a frustrated $\mathrm{Li}^{+}$lattice [53]. In addition, a solid-state nuclear magnetic resonance (NMR) study of the spin-lattice relaxation in $\mathrm{Na}_{2} \mathrm{~B}_{12} \mathrm{H}_{12}$ salts revealed a substantial increase in the reorientational jump rates of $\mathrm{B}_{12} \mathrm{H}_{12}{ }^{2-}$ accompanied by the fast translational diffusion of $\mathrm{Na}^{+}$following a first-order transition near $520 \mathrm{~K}$ [54]. Interestingly, investigating closo-borates as solid electrolytes for $\mathrm{Li}$ and $\mathrm{Na}$ batteries was reported concurrent with the report of $\mathrm{Mg}$ closo-borate salts as competent liquid electrolytes for $\mathrm{Mg}$ batteries- owing to their compatibility with Mg metal anode and high anodic stability- as discussed in Section 4 [9].

High cationic translational mobility in boron clusters was first reported for hydroborates in $\mathrm{Na}_{2} \mathrm{~B}_{12} \mathrm{H}_{12}$ where high $\mathrm{Na}^{+}$conductivity in the order of $10^{-1} \mathrm{~S} / \mathrm{cm}$, near $540 \mathrm{~K}$ was obtained (Figure 3) [55]. These conductivities were observed following transition from a low-temperature (ordered monoclinic) to a high-temperature (disordered, body-centered cubic) phase and were consistent with ${ }^{23} \mathrm{Na} \mathrm{NMR}$ measurements that showed enhancements in $\mathrm{Na}^{+}$cation jump rate $\left(>2 \times 10^{8}\right.$ jumps/s) in the high temperature polymorph [54]. Lowering the transition temperature to a super conductor was reported for $\mathrm{Na}_{2} \mathrm{~B}_{10} \mathrm{H}_{10}$, where a disordered face-centered cubic phase $(>360 \mathrm{~K})$, allowed for high $\mathrm{Na}$ conductivities in the order of $0.01 \mathrm{~S} / \mathrm{cm}$ at $383 \mathrm{~K}$ [56]. One source of this improvement was speculated to result from the less spherical $\mathrm{B}_{10} \mathrm{H}_{10}{ }^{2-}$ anion which offered improved cationic diffusion. Results suggested that the anion dynamics was one major contributors to the conduction of the cation. For example, ab initio molecular dynamics (AIMD) simulations showed that the $\mathrm{Li}^{+}$ ion diffusivity in $\beta-\mathrm{Li}_{2} \mathrm{~B}_{12} \mathrm{H}_{12}$ would be reduced by three orders of magnitude if the anion was constrained and immobile [57]. Computational studies however also showed that anionic dynamics (rotation/vibrations), is not the only factor that dictates the cationic mobility, rather, it is a complex interplay between the density of accessible diffusion sites, anionic dynamics and the nature of local bonding [58].

The relatively high mobility of $\mathrm{Na}^{+}$in closo-borates triggered further studies to further improve the room temperature ionic conductivity. Similar approaches to those proven successful in enhancing the conductivity of $\mathrm{Li}^{+}$in $\mathrm{LiBH}_{4}$ were implemented such as partial substitution with another anion including $\mathrm{BH}_{4}{ }^{-}$and a halide $(\mathrm{Br}, \mathrm{Cl}, \mathrm{I})$ or with a cation like $\mathrm{Li}^{+}[59,60]$. The absence of order-disorder transition and high room temperature conductivity $\left(0.5 \times 10^{-3} \mathrm{~S} / \mathrm{cm}\right)$ for $\mathrm{Na}_{3} \mathrm{BH}_{4} \mathrm{~B}_{12} \mathrm{H}_{12}$ suggested that the anion dynamics were a less important contributor to the superconductivities and that structural factors were more at play in this case. Cationic substitution was reported to enhance the ionic conductivity as in $\mathrm{LiNaB}_{12} \mathrm{H}_{12}$ (i.e., at $550 \mathrm{~K}$, the conductivity was eight times higher than $\mathrm{Na}_{2} \mathrm{~B}_{12} \mathrm{H}_{12}$ ). Both $\mathrm{Li}^{+}$ and $\mathrm{Na}^{+}$cations were mobile; $\mathrm{Na}^{+}$became more mobile between $393 \mathrm{~K}$ to $433 \mathrm{~K}$ as suggested by the decreased $\mathrm{Li}^{+}$transference number, respectively, from 0.91 to 0.71 [60]. However, these improvements in conductivity were later suggested to result from the inadvertent presence of other cluster fragments, i.e., $\mathrm{B}_{10} \mathrm{H}_{10}{ }^{2-}$, produced from the synthesis of the salts using $\mathrm{B}_{10} \mathrm{H}_{14}$. For example, intentional inclusion of $\mathrm{B}_{10} \mathrm{H}_{10}{ }^{2-}$ in the structure of $\mathrm{Na}_{2} \mathrm{~B}_{12} \mathrm{H}_{12}$ or simply preparing a binary complex of these anions dramatically enhanced the cationic conductivity $[61,62]$. It is noteworthy to mention that similar effects of these fragments on improving the cationic conductivity of $\mathrm{Li}_{2} \mathrm{~B}_{12} \mathrm{H}_{12}\left(10^{-4} \mathrm{~S} / \mathrm{cm}\right)$, prepared from $\mathrm{B}_{10} \mathrm{H}_{14}$ [63]; believed to result from a brief ball milling, were also suggested [64]. Systematic studies of possible extended ball milling effects on conductivity improvement in several boron cluster salts free from other undetermined cluster fragments were later reported, aided by powder x-ray diffraction (PXRD) and Quasielastic Neutron Scattering (QENS). The main finding was that ball milling resulted in the presence of the high temperature disordered phase at room temperature in the processed materials, which suggested a stabilized room temperature disordered form [65]. Conductivity enhancements were drastic, i.e., at room temperature the conductivity for $\mathrm{Na}_{2} \mathrm{~B}_{12} \mathrm{H}_{12}$ was three orders of magnitude higher than that of the pristine sample. It is interesting that these ball-milled electrolytes consisted of both the low conducting and superconducting phases, where the latter phase was present in a form of interconnected nanocrystallites that were distributed in larger crystallites, which exhibited typical bulk-like conductivities [65]. Revisiting the ball milling effects on the conductivity of fragment-free 
$\mathrm{Li}_{2} \mathrm{~B}_{12} \mathrm{H}_{12}$ (measured in the order of $10^{-5} \mathrm{~S} / \mathrm{cm}$ at room temperature) was conducted in a later study. This work revealed that the improvements were due to $\mathrm{Li}^{+}$and $\mathrm{H}$ deficiencies and proposed that these enhancements were unlikely to result from a stabilization effect of the high temperature phase as was evident from structural analysis. [66] What stands out in this study is the finding that deficiencies of $\mathrm{H}$ in boron clusters, that are stabilized by the cation, could be utilized to improve cationic mobilities.

To further improve the cationic conductivity, the utilization of carborate boron clusters, which carry a mononvalent negative charge, was investigated for $\mathrm{LiCB}_{11} \mathrm{H}_{12}$ and $\mathrm{NaCB}_{11} \mathrm{H}_{12}$ [67]. Interestingly, $\mathrm{LiCB}_{11} \mathrm{H}_{12}$ and $\mathrm{NaCB}_{11} \mathrm{H}_{12}$ underwent transition to a superconducting $(>0.1 \mathrm{~S} / \mathrm{cm})$ disordered phase at much lower temperatures, $400 \mathrm{~K}$ and $380 \mathrm{~K}$, respectively (Figure 3), accompanied by a high rate of anion reorientational jumps $\left(10^{10}-10^{11} \mathrm{jumps} / \mathrm{s}\right)$. The cluster's monovalent charge, presence of less neighbors (cation:anion molar ratio $=1: 1$ ), and increased lattice constant were hypothesized to cause these enhanced conductivities. These were confirmed from ab initio molecular dynamics (AIMD) which also demonstrated that formation of a dipole (carbon atoms), creates a frustrated lattice and counteracts the ability of the phase to order, thereby reducing the transition temperature to superconducting phases [68].

Inspired from improvements in conductivity observed using the smaller $\mathrm{B}_{10} \mathrm{H}_{10}{ }^{2-}$, studies examined $\mathrm{Li}$ and $\mathrm{NaCB}_{9} \mathrm{H}_{10}$ salts and demonstrated impressive room temperature conductivities of about 0.03 $\mathrm{S} / \mathrm{cm}$ in the Na salt (Figure 3). Achieving this conductivity required preheating (i.e., sample conditioning to access the superconducting phase) to about $425 \mathrm{~K}$ [69]. Note that systematic studies on the effect of thermal cycling on the room temperature stability of the disordered superconducting phase are needed to discern the origin of these drastic improvements, especially given the hysteresis observed. Substantial improvements were also found for the Li-based salt (Figure 3), i.e., $0.03 \mathrm{~S} / \mathrm{cm}$ at $354 \mathrm{~K}$. As the case in $\mathrm{NaCB}_{11} \mathrm{H}_{12}$ and $\mathrm{LiCB}_{11} \mathrm{H}_{12}$ salts, the dipole produced by the carbon atom could influence the anion orientations and create a frustrated landscape that results in high cationic mobility at lower temperatures.

Further studies with $\mathrm{Na}$ and $\mathrm{Li}$ carborate salts targeted stabilization studies of the high temperature superconducting phase and were inspired by those implemented in borohydrides and hydroborates. Stabilization of the disordered phase was studied through formation of what was suggested as mixed $\left(\mathrm{CB}_{9} \mathrm{H}_{10}: \mathrm{CB}_{11} \mathrm{H}_{12}\right)^{2-} \mathrm{Li}$ and $\mathrm{Na}$ salts $[64,65]$. These salts were produced from mechanochemical treatment or simple mixing of $\left(\mathrm{CB}_{9} \mathrm{H}_{10}: \mathrm{CB}_{11} \mathrm{H}_{12}\right)^{2-} \mathrm{Li}$ and $\mathrm{Na}$ salts in the 1:1 molar ratio in aqueous solutions. The absence of phase transitions suggested some sort of stabilization effect on the disordered phases. High ionic conductivity of $\mathrm{Li}^{+}$was found $\left(10^{-3} \mathrm{~S} / \mathrm{cm}\right.$ at $\left.300 \mathrm{~K}\right)$, and impressive $\mathrm{Na}^{+}$conductivity was reported $\left(6 \times 10^{-2} \mathrm{~S} / \mathrm{cm}\right.$ at $\left.300 \mathrm{~K}\right)$. A recent report examined the $\mathrm{Li}$ salt conductivity in mixed 7:3 molar $\mathrm{CB}_{9} \mathrm{H}_{10}{ }^{-}: \mathrm{CB}_{11} \mathrm{H}_{12}{ }^{-}$prepared by ball milling also demonstrated very high conductivity of $6.7 \times 10^{-3} \mathrm{~S} / \mathrm{cm}$ at room temperature without thermal activation (Figure 4) [70]. Other studies examined mixing $\mathrm{Na}$ carborate $\mathrm{CB}_{11} \mathrm{H}_{12}{ }^{-}$with hydroborate $\mathrm{B}_{12} \mathrm{H}_{12}{ }^{-}$salts and also showed high conductivities $\left(2 \times 10^{-3} \mathrm{~S} / \mathrm{cm}\right.$ at room temperature), albeit lower than those observed for closo-carborates [71]. Studies in carborate-type derivatives based on several nido-carborates demonstrated inferior conductivities to those reported in closo-carborates [72] (note: surprisingly a high value in the order of $10^{-3} \mathrm{~S} / \mathrm{cm}$ at $300 \mathrm{~K}$ was reported for what was described as $\alpha-\mathrm{NaCB}_{11} \mathrm{H}_{14}$, it remains unclear why the conductivity was much higher than that in typical $\mathrm{NaCB}_{11} \mathrm{H}_{14}, 10^{-6} \mathrm{~S} / \mathrm{cm}$ at $300 \mathrm{~K})$. Although, the electrochemical stabilities of these specific salts were not reported, they are expected to exhibit a much narrower window compared to the closo-borates owing to the known limited stability of the nido-anions [72]. 

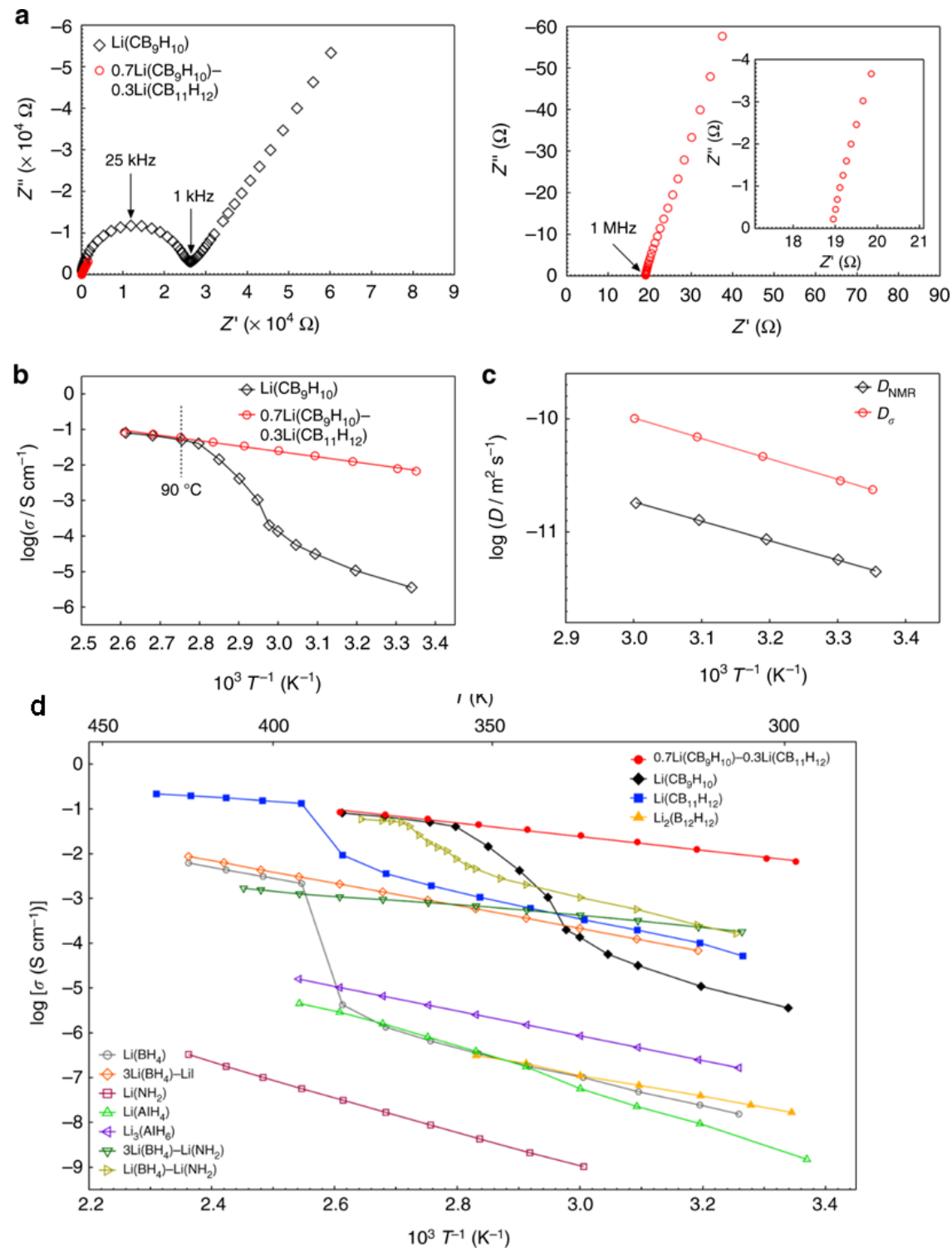

Figure 4. Lithium ion conductivity of 7:3 molar $\left(\mathrm{CB}_{9} \mathrm{H}_{10}: \mathrm{CB}_{11} \mathrm{H}_{12}\right)^{2-}$ Li salt. (a) Nyquist plots at room temperature and magnified Nyquist plots, (b) Arrhenius plots of the lithium ion conductivity, (c) Arrhenius plots of the diffusion coefficients calculated from the impedance and nuclear magnetic resonance (NMR) measurements, (d) Arrhenius plots comparing the conductivity for variety of Li salts. Reprinted with permission from reference [70], copyright 2019 Macmillan Publishers Limited, part of Springer Nature.

One approach sought to increase the conductivity in $\mathrm{B}_{12} \mathrm{H}_{12}{ }^{2-}$ by confinement in a nanoporous silica SBA scaffold, which was inspired from $\mathrm{LiBH}_{4}$ studies discussed above [73]. However, nanoconfinement in the case of $\mathrm{Li}_{2} \mathrm{~B}_{12} \mathrm{H}_{12}$ was not effective as was evident from a very low conductivity compared to that of the bulk material (i.e., $10^{-7} \mathrm{~S} / \mathrm{cm}$ at room temperature).

It is worth noting there have been studies that investigated the cationic conductivities in boron clusters that were halogenated. Replacing the hydrogens in the $\mathrm{B}_{12} \mathrm{H}_{12}{ }^{2-}$ anion with halogens in the $\mathrm{Na}$ salt was counterproductive and showed dramatically low conductivities at room temperature, where high conductivities in the order of $10^{-1} \mathrm{~S} / \mathrm{cm}$, could only be achieved at temperatures exceeding $673 \mathrm{~K}$. This behavior was suggested to result from restriction in cluster's reorientational mobility, caused by increased anionic mass wherein strong bonds to $\mathrm{Na}^{+}$as a result of directional charge distribution on the halogen atoms, contributed to this behavior [74]. A recent computational study supported this finding and 
suggested that partial halogenation may somewhat reduce conductivity losses in halogenated $\mathrm{B}_{12} \mathrm{H}_{12}{ }^{2-}$, however the conductivity will be lower than the hydrogenated form [75].

\section{Electrolytes for Multivalent Batteries}

Recently, there have been increased interests in post lithium batteries that include multivalent storage cations such as $\mathrm{Al}^{3+}, \mathrm{Ca}^{2+}$ or $\mathrm{Mg}^{2+}$ [2]. These elements are abundant and offer possibilities for battery cost reductions. In addition, their use in the form of metallic anodes offer a safer alternative to reactive Li metal. In particular, magnesium batteries attracted lots of interest due to their high energy density potential. The $\mathrm{Mg}$ metal redox potential is low ( $-2.4 \mathrm{~V}$ vs. SHE) and it has high volumetric capacity (3832 mAh/cm vs. $2062 \mathrm{mAh} / \mathrm{cm}$ and $1136 \mathrm{mAh} / \mathrm{cm}$, for Li and Na, respectively) [6]. One key hurdle in these batteries is the passivation of $\mathrm{Mg}$ metal, due to electrolyte decomposition, in most common salts/solvents in addition to the sluggish diffusion kinetics of $\mathrm{Mg}^{2+}$ in solid-state host structures likely caused by its divalent charge [76,77].

Until recently, the $\mathrm{Mg}$ passivation challenge has limited the choice of electrolytes to a handful of chloride base salts/reagents as they were not shown to passivate $\mathrm{Mg}$ metal [2,6]. These electrolytes, while highly performing, are corrosive, have limited anodic stability (i.e., limited by $\mathrm{Cl}^{-}$redox potential) and negatively interfere with cation insertion in the cathode [78]. Although designing other alternatives that overcome these challenges seemed farfetched, boron hydrogen compounds were discovered to offer highly competent and practical Mg electrolytes. As similar passivation issues that occur on $\mathrm{Mg}$ metal are encountered for Ca metal, strategies that were successful in $\mathrm{Mg}$ batteries were shown as applicable to Ca batteries.

\subsection{Liquid Borohydride Electrolytes: Achieving Compatibility with Mg Metal}

The notion that simple ionic Mg salts could not function in Mg batteries was altered in 2012, where $\mathrm{Mg}\left(\mathrm{BH}_{4}\right)_{2}$ was demonstrated as a first example of halogen-free, simple-type ionic electrolyte in $\mathrm{Mg}$-based batteries [79]. The heart of this concept was that the high reductive stability of $\mathrm{Mg}\left(\mathrm{BH}_{4}\right)_{2}$ (i.e., reducing agent) would allow it to withstand the low potential environment of $\mathrm{Mg}$ metal anode thereby preventing $\mathrm{Mg}$ metal passivation. Ethereal solutions of $\mathrm{Mg}\left(\mathrm{BH}_{4}\right)_{2}$ in tetrahydrofuran (THF) solvent enabled reversible $\mathrm{Mg}$ plating/stripping. This proof of concept sparked research efforts towards understanding the scarcely explored aprotic solution chemistry of hydrides in order to improve the performance of these electrolytes by determining key factors that govern their electrochemical behavior. Spectroscopic analyses (FTIR, NMR) revealed that the electrochemical performance was dictated by poor dissociation in low dielectric solvents such as THF (owing to the relatively ionic nature of the salt). This was overcome using ethereal solvents with more electron donating oxygen sites such as 1,2 dimethoxyethane (DME) and the addition of additives that further dissociate $\mathrm{Mg}\left(\mathrm{BH}_{4}\right)_{2}$ such as $\mathrm{LiBH}_{4}$, through potential complexation of the acidic cation with the $\mathrm{BH}_{4}{ }^{-}$. The combination of the aforementioned strategies resulted in a competent performance (Figure 5) with high current densities ( $25 \mathrm{~mA} / \mathrm{cm}^{2}$ stripping peak current), low deposition $(-0.3 \mathrm{~V}) /$ stripping $(0 \mathrm{~V})$ overpotentials and excellent $\mathrm{Mg}$ deposition/stripping coulombic efficiency (94\%). These findings demonstrated that simple ionic salts could be made compatible with the magnesium metal if the anion in the salt has sufficient reductive stability, thereby creating a new design space of highly performing electrolytes for $\mathrm{Mg}$ batteries. The electrochemical performance was found to be governed by the extent of salt dissociation per spectroscopic analyses which revealed the presence of strong association in these electrolytes. The amount of the complex cation $\mathrm{MgBH}_{4}{ }^{+}$(i.e., charge carrier) tracked with improved electrochemical performance. Follow up studies examined other chelating solvents such diglyme (DGM) and tetraglyme, which further demonstrated the direct relationship between the number of electrodonating oxygen sites and the coulombic efficiency of Mg plating/stripping [80,81]. In addition, computations were used to understand the role of coordination and the effects of the solvent on the solubility and dissociation in these electrolytes [82,83]. Significant and irreversible salt agglomeration in all glymes ranging from THF to tetraglyme was found in all non-dilute borohydride salt solutions [82]. 
The agglomeration rate and diffusivity of $\mathrm{Mg}^{2+}$ in longer chain ethers such as tetraglyme were at their lowest and tracked with the solvent's self-diffusivity.

The report of $\mathrm{Mg}\left(\mathrm{BH}_{4}\right)_{2}$ as a competent electrolyte sparked interests in revisiting other ionic salts such as magnesium bis(trifluoromethanesulfonyl)imide $\mathrm{Mg}(\mathrm{TFSI})_{2}$, known to passivate $\mathrm{Mg}$ metal $[84,85]$. Similar solution chemistry dominated by $\mathrm{Mg}$ association with the anion was found in $\mathrm{Mg}(\mathrm{TFSI})_{2}$ electrolytes [86], which underscored the importance of the high reductive stability of the $\mathrm{BH}_{4}{ }^{-}$anion in preventing passivation of $\mathrm{Mg}$ metal.

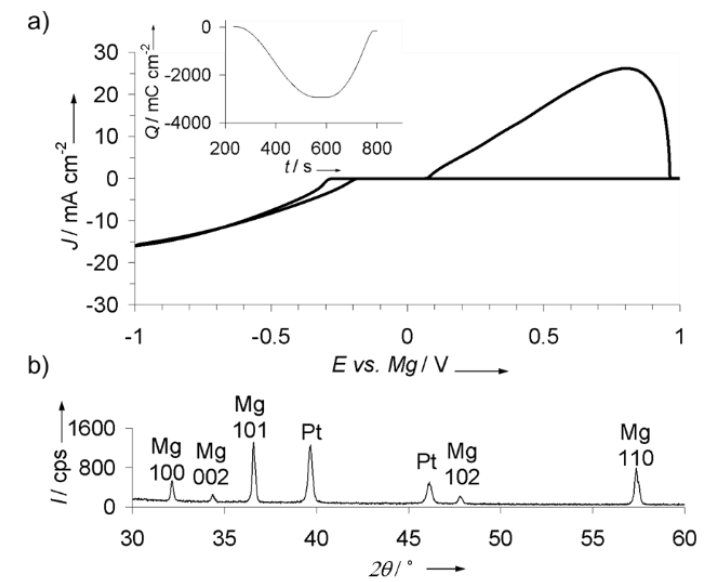

c)

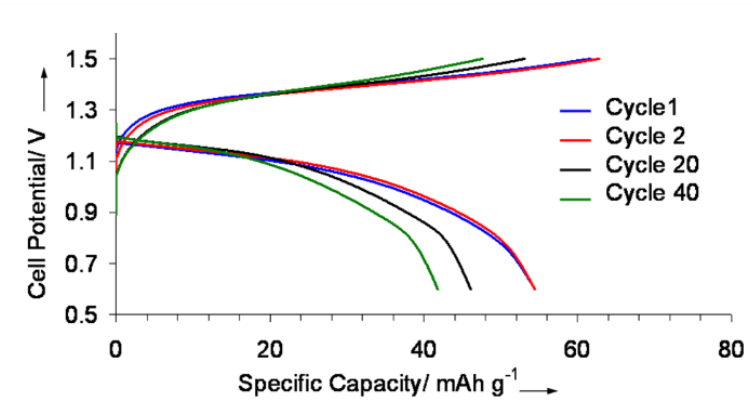

Figure 5. Performance of $\mathrm{Mg}$ borohydride electrolyte: (a) Cyclic voltammogram (inset shows deposition/stripping charge balance) in 1:3 molar $\mathrm{Mg}\left(\mathrm{BH}_{4}\right)_{2}: \mathrm{LiBH}_{4}$ in 1,2 dimethoxyethane (DME), (b) XRD results following galvanostatic deposition of $\mathrm{Mg}$ metal, (c) Battery cycling with this electrolyte. Reprinted from reference [79] with permission. Copyright (C) 2012, Wiley-VCH Verlag GmbH and Co. KGaA, Weinheim.

$\mathrm{Mg}\left(\mathrm{BH}_{4}\right)_{2}$ was applied to mitigate the passivation effects that take place in the presence of $\mathrm{Mg}$ passivating anions, i.e., TFSI, present in inorganic salts $\left(\mathrm{Mg}(\mathrm{TFSI})_{2}\right)$ [87], in organic salts (ionic liquids solvents) $[88,89]$ and as a reagent in complex electrolyte solutions such as alkoxyborates (i.e., mixing the acidic tris(2H-hexafluoroisopropyl) borate (THFPB) with $\mathrm{Mg}\left(\mathrm{BH}_{4}\right)_{2}$ to study $\mathrm{Mg}$-S batteries) [90]. Note that in the latter case, reaction of the reductive borohydride with the acidic additive was indicated thereby partially transforming the borohydride (further investigation is needed to identify the new species). Another approach that was applied to modify $\mathrm{Mg}(\mathrm{TFSI})_{2}$ solutions with $\mathrm{BH}_{4}{ }^{-}$was using a $\mathrm{BH}_{4}{ }^{-}$anion with hydride groups that were partially substituted with phenol [91]. Both $0.5 \mathrm{M} \mathrm{Mg}(\mathrm{TFSI})_{2}$ and $0.15 \mathrm{M} \mathrm{Mg}\left(\mathrm{B}(\mathrm{OPh})_{3} \mathrm{H}\right)_{2}$ were combined in diglyme and exhibited low deposition overpotentials ( $c a$ $-0.64 \mathrm{~V})$; however, the coulombic efficiency remained at low as $64 \%$ even after extended cycling [91].

The successes with utilizing magnesium borohydride in $\mathrm{Mg}$ batteries later inspired examining borohydrides electrolytes for Ca batteries, wherein Ca metal anode is notorious for being easily passivated by common electrolytes. $\mathrm{Ca}\left(\mathrm{BH}_{4}\right)_{2}$ in tetrahydrofuran (THF) electrolyte was remarkably capable of plating/stripping Ca metal with high coulombic efficiencies, high purity and current densities (Figure 6) [92]. 


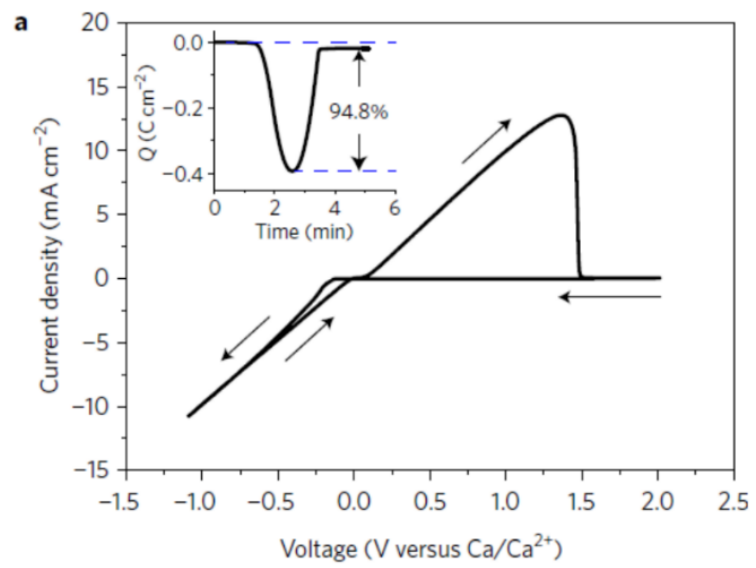

b

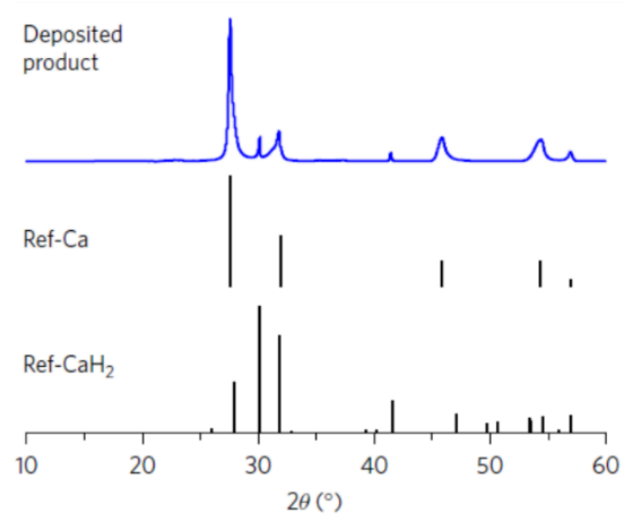

Figure 6. $\mathrm{Ca}\left(\mathrm{BH}_{4}\right)_{2} / \mathrm{THF}$ electrolyte for Ca battery: (a) Electrochemical results of calcium plating/stripping in $1.5 \mathrm{M} \mathrm{Ca}\left(\mathrm{BH}_{4}\right)_{2} / \mathrm{THF},(\mathbf{b})$ Powder X-ray diffraction demonstrating Ca plating from the electrolyte. Reprinted with permission from reference [92], copyright 2017 Macmillan Publishers Limited, part of Springer Nature.

\subsection{Electrolytes with Wide Electrochemical Window: Closo-Borate Salts}

The stability against electrochemical oxidation of borohydrides in ethereal solutions was found low in all magnesium borohydride based electrolytes (i.e., 1.7, 2.2 and $2.3 \mathrm{~V} \mathrm{vs.} \mathrm{Mg} / \mathrm{Mg}^{2+}$ ) on platinum, stainless steel and glassy carbon electrodes, respectively) [79]. This, coupled with the highly nucleophilic nature, limit the use of borohydrides electrolytes under a high voltage environment and with cathodes susceptible to nucleophilic attacks such as S or some oxides. To increase the oxidative stability of the $\mathrm{Mg}\left(\mathrm{BH}_{4}\right)_{2}$ electrolytes, and minimize their hydridic reactive character, strengthening of the B-H bond through forming 3-dimensional B-B bonds as in icosahedral boron clusters (hydroborates and carborates) was proposed and demonstrated using closo-carborates [9,93,94]. The concept was that these clusters would retain the high compatibility of the B-H based salt with Mg metal, whilst expanding the electrochemical stability window. Computational and experimental support of this concept was first presented using the dicarborate anion, where carboranyl magnesium chloride electrolyte $\left(1-\left(1,7-\mathrm{C}_{2} \mathrm{~B}_{10} \mathrm{H}_{11}\right) \mathrm{MgCl}\right)$ was reported with high oxidative stability $(3.3 \mathrm{~V} \mathrm{vs.} \mathrm{Mg})$ (Figure 7). The electrolyte also demonstrated the high compatibility of the carborate anion with $\mathrm{Mg}$ metal (i.e., columbic efficiency was $c a 100 \%$ ). Based on this proof of concept, a new simple salt based on the more weakly coordinating monocarborate anion $\mathrm{CB}_{11} \mathrm{H}_{12}{ }^{-}$was synthesized and reported with high solubility in triglyme and tetraglyme (>1M) [94]. The electrolyte efficiently cycled $\mathrm{Mg}$ metal (>98\%) with very low overpotentials, had high chemical stability and was non corrosive. In addition, unlike the case in the borohydride electrolytes, the $\mathrm{Mg}^{2+}$ in this electrolyte was found be unassociated with the anion as revealed in the crystal structure of the isolated salt (Figure 7). It is worth mentioning that the oxidative stability of $\mathrm{Mg}\left(\mathrm{CB}_{11} \mathrm{H}_{12}\right)_{2}$ (measured in acetonitrile solvent), was found to be very high $\left(4.9 \mathrm{~V}\right.$ vs. $\mathrm{Mg} / \mathrm{Mg}^{2+}$ ) which exceeds that of all ether solvents. These remarkable properties qualified the report of this electrolyte as a breakthrough in the field of $\mathrm{Mg}$ electrolytes [2]. A follow up study reported the retention of $\mathrm{Mg}$ metal compatibility after fluorination of the $\mathrm{C}-\mathrm{H}$ bond in the $\mathrm{CB}_{11} \mathrm{H}_{12}{ }^{-}$ anion, as was apparent from high coulombic efficiencies (96\%) and low overpotentials (measured in $5 \mathrm{mM}$ salt concentrations in triglyme) [95]. 
a

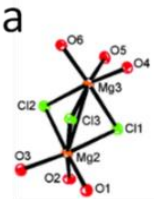

b

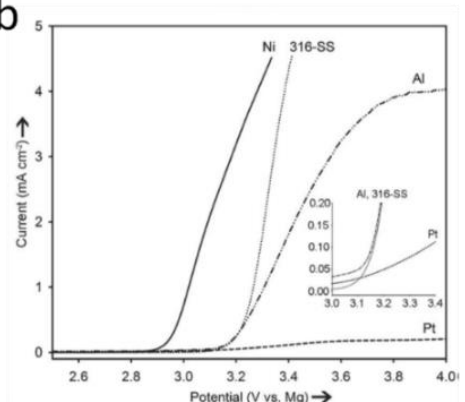

c

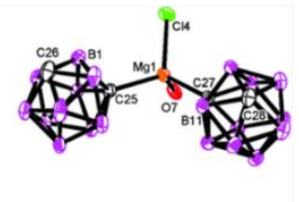

f

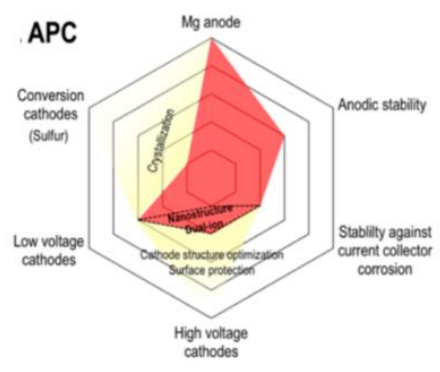

MACC

Mganode

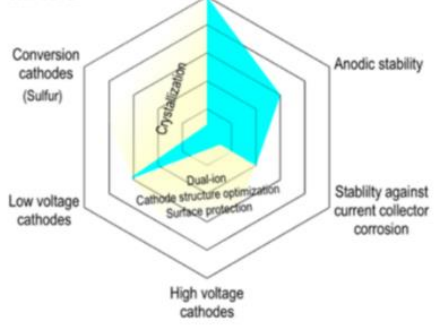

Conventional Mganode

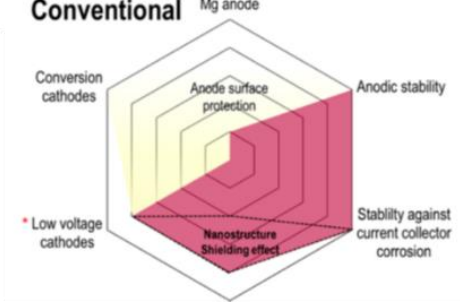

d
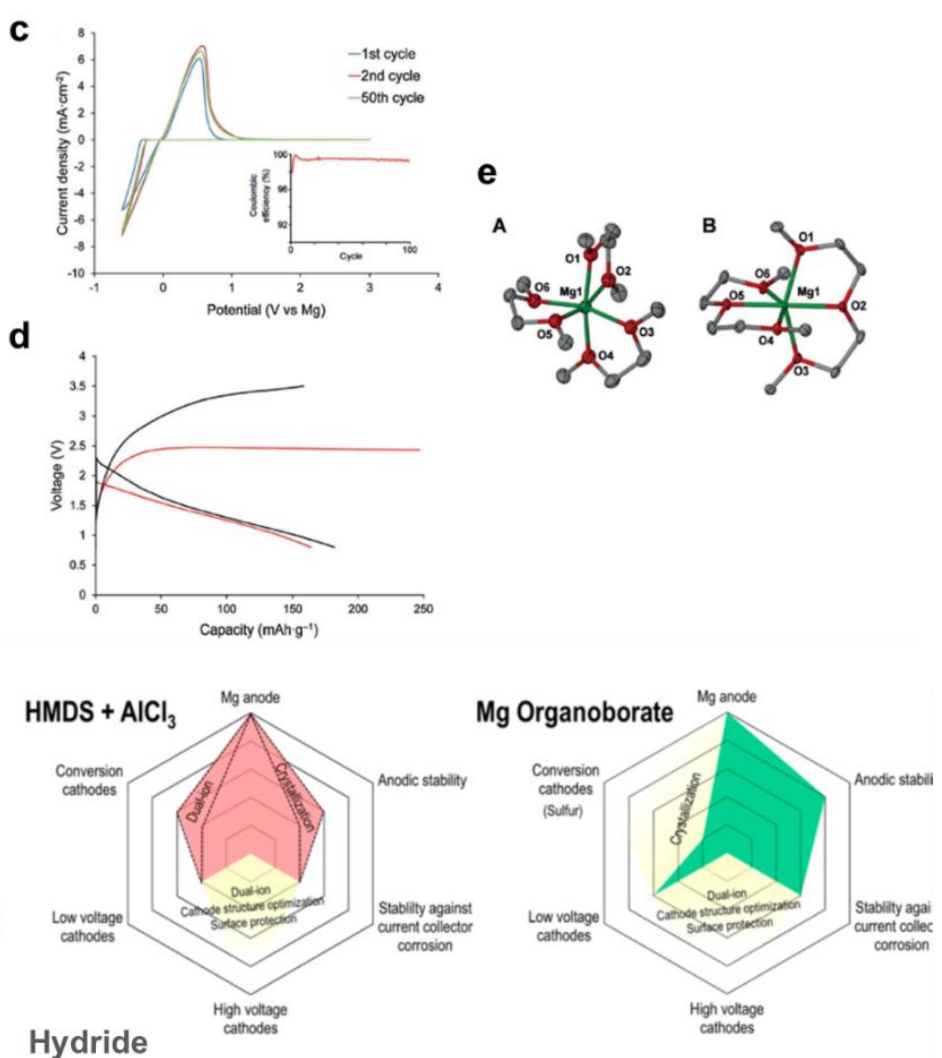

Hydride

Boron-cluster

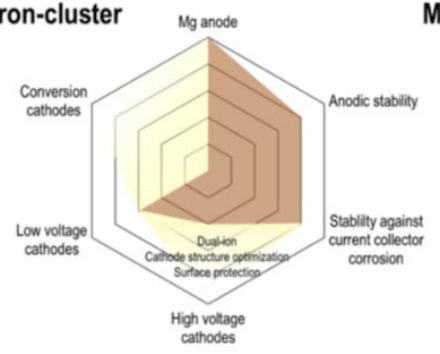

$\mathrm{Mg}(\mathrm{TFSI})_{2}+\mathrm{MgCl}_{2}$

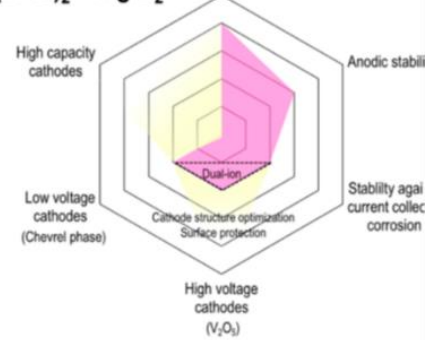

Figure 7. For 1-(1,7- $\left.\mathrm{C}_{2} \mathrm{~B}_{10} \mathrm{H}_{11}\right) \mathrm{MgCl}$ electrolyte: (a) Molecular structure and (b) Oxidative stability. Reprinted from reference [93] with permission from Wiley-VCH Verlag GmbH and Co. KGaA, Weinheim, Copyright 2014. For $\mathrm{Mg}\left(\mathrm{CB}_{11} \mathrm{H}_{12}\right)_{2}$ /tetraglyme electrolyte: (c) Cyclic voltammograms on Pt, (d) Initial discharge-charge profiles of a rechargeable $\mathrm{Mg}$ battery with $\mathrm{Mg}\left(\mathrm{CB}_{11} \mathrm{H}_{12}\right)_{2}$ /tetraglyme (black line) and chlorophenyl aluminate electrolyte $\mathrm{APC}$ (red line) as the electrolyte, a $\mathrm{Mg}$ anode, and $\alpha-\mathrm{MnO}_{2}$ cathode, (e) Mg cation coordination environment in monoglyme (A) and diglyme (B). Reprinted from reference [94] with permission from Wiley-VCH Verlag GmbH and Co. KGaA, Weinheim, Copyright 2015. (f) Position of hydride liquid electrolytes (boron clusters) amongst other Mg battery electrolytes. Reprinted from reference [96] with permission from the American Chemical Society, Copyright 2016. 


\subsection{Hydride Interfaces in Multivalent Batteries: Significance and Nature}

It has been generally accepted that the formation of interfaces on the surface of multivalent metal anodes such as Mg would lead to passivation phenomena, thereby prohibiting the function of the battery. This is interestingly in stark contrast with Li or Na based batteries, where these interfaces or solid electrolyte interfaces (SEIs) (resulting from decomposition of the electrolyte), are permeable to $\mathrm{Na}^{+}, \mathrm{Li}^{+}$and are instrumental in enabling a stable performance of the anode $[97,98]$. The root causes of these passivating phenomena are not well understood and could likely result from the divalent nature of these ions which results in low diffusivity in the solid state.

Recently, research into the function of hydrides electrolytes in $\mathrm{Mg}$ and Ca batteries revealed the presence of $\mathrm{Mg}$ and $\mathrm{Ca}$ interfaces that could support highly efficient deposition/stripping of these multivalent metals. This indeed alters the notion of what has been widely understood about factors required to support the function of these anodes [2]. The first evidence of $\mathrm{Mg}^{2+}$ permeable SEI in Mg batteries was shown in the borohydride solutions [99]. The properties of the interface were demonstrated to play an important role in the performance of the electrolyte. For example, the presence of the SEI was observed in $\mathrm{Mg} / \mathrm{Mg}$ symmetric cells and was found to be dependent on the type of solvent and borohydride additive used, i.e., the use of monoglyme solvent and $\mathrm{LiBH}_{4}$ additive (in the 1:3 molar $\mathrm{Mg}\left(\mathrm{BH}_{4}\right)_{2}: \mathrm{LiBH}_{4} / \mathrm{DME}$ electrolyte) resulted in the lowest cell overpotentials [99]. Therefore detailed investigations of the nature of this interface and morphology were conducted using operando electrochemical-synchrotron soft X-ray absorption (sXAS) and transmission electron microscopy (TEM) [99]. Chemical transformation of the $\mathrm{BH}_{4}{ }^{-}$, accompanied by $\mathrm{H}_{2}$ gas release, into $\mathrm{B}_{12} \mathrm{H}_{12}{ }^{2-}$, was observed to occur during the $\mathrm{Mg}$ deposition process (Figure 8). It is worth noting that the formation of $\mathrm{Mg}$ rich, Li poor alloy was observed in the 1:6 molar $\mathrm{Mg}\left(\mathrm{BH}_{4}\right)_{2}: \mathrm{LiBH}_{4} /$ diglyme electrolyte and was suggested to play a role in the Mg deposition process [100]. However, the formation of this alloy seems to be limited thus far to this $\mathrm{LiBH}_{4}$ rich mixture as $\mathrm{Li}$ presence was not found in the 1:3 molar $\mathrm{Mg}\left(\mathrm{BH}_{4}\right)_{2}: \mathrm{LiBH}_{4} / \mathrm{DME}$ electrolyte [99]. SEI presence was also revealed in $\mathrm{Mg}\left(\mathrm{CB}_{11} \mathrm{H}_{12}\right)_{2}$ electrolytes and constituted of $\mathrm{Mg}, \mathrm{B}$ and $\mathrm{C}$ species, in addition to a crystalline phase indexed to be close to a $\mathrm{MgB}_{2} \mathrm{O}_{5}$ like species [101,102]. The deposited magnesium was found to be in the form of $\mathrm{Mg}$ nanoparticles ( $c a 10 \mathrm{~nm}$ ) embedded in an amorphous matrix of SEI material whose growth was captured. This morphology and resultant SEI enabled cycling $\mathrm{Mg} / \mathrm{Mg}$ symmetric cells under unprecedented high current rate conditions $\left(10 \mathrm{~mA} \mathrm{~cm}^{-2}\right)$ [102].
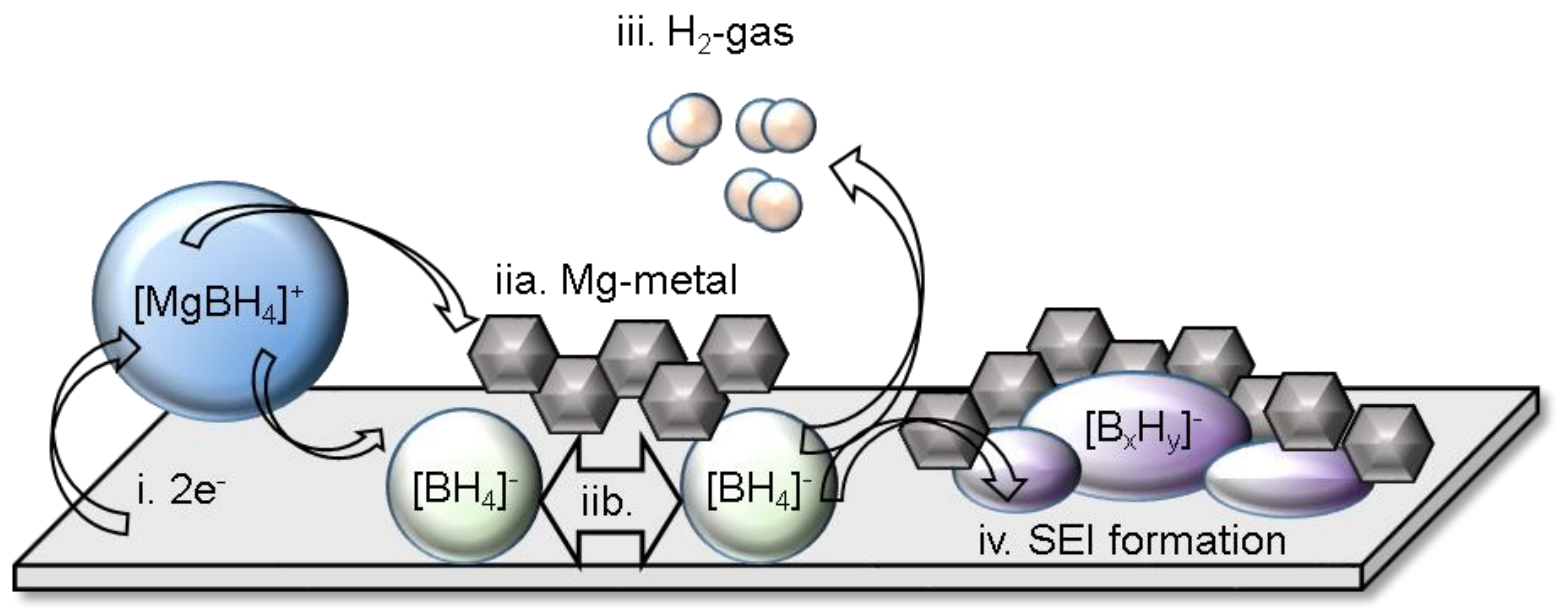

Figure 8. Formation of interface in $\mathrm{Mg}$ interface in $\mathrm{Mg}\left(\mathrm{BH}_{4}\right)_{2}: \mathrm{LiBH}_{4} / \mathrm{DME}$ electrolyte. Reprinted from reference [99], permission of the American Chemical Society, copyright 2017.

In $\mathrm{Ca}$ batteries, the presence of $\mathrm{CaH}_{2}$ on the surface of $\mathrm{Ca}$ metal, formed from the reaction between the THF solvent and Ca metal was revealed [92]. The non-reactivity of $\mathrm{Ca}\left(\mathrm{BH}_{4}\right)_{2}$ with the hydride could be the source of the high compatibility in this case. No detailed investigation of possible SEI 
formation under high currents were reported and further understanding of factors that govern these performances is desired.

\subsection{Solid-State Electrolytes}

The divalent positive charge carried by cations such as $\mathrm{Mg}^{2+}$ leads to sluggish diffusion kinetics in solid-state structures. As such, designing electrolytes with acceptable $\mathrm{Mg}^{2+}$ conductivity has been very challenging. However, the report of highly $\mathrm{Mg}$ compatible $\mathrm{Mg}\left(\mathrm{BH}_{4}\right)_{2}$-based materials as liquid electrolytes, stimulated research that investigated $\mathrm{Mg}$ borohydride-based salts as solid electrolytes. This was first demonstrated for $\mathrm{Mg}\left(\mathrm{BH}_{2}\right)\left(\mathrm{NH}_{2}\right)$, selected due to the presence of cavities large enough to enable magnesium ion conduction through the hopping mechanism. Conductivity of about $10^{-3} \mathrm{mS} / \mathrm{cm}$ was measured at $423 \mathrm{~K}$ for $\mathrm{Mg}\left(\mathrm{BH}_{4}\right)\left(\mathrm{NH}_{2}\right)$, which is three orders of magnitude higher than that in $\mathrm{Mg}\left(\mathrm{BH}_{4}\right)_{2}$, presumably due to the shorter distance between the two nearest $\mathrm{Mg}$ atoms (3.59 $\AA$ in $\mathrm{Mg}\left(\mathrm{BH}_{4}\right)\left(\mathrm{NH}_{2}\right)$ vs. $4.32 \AA$ in $\left.\mathrm{Mg}\left(\mathrm{BH}_{4}\right)_{2}\right)$ (Figure 9) [103].

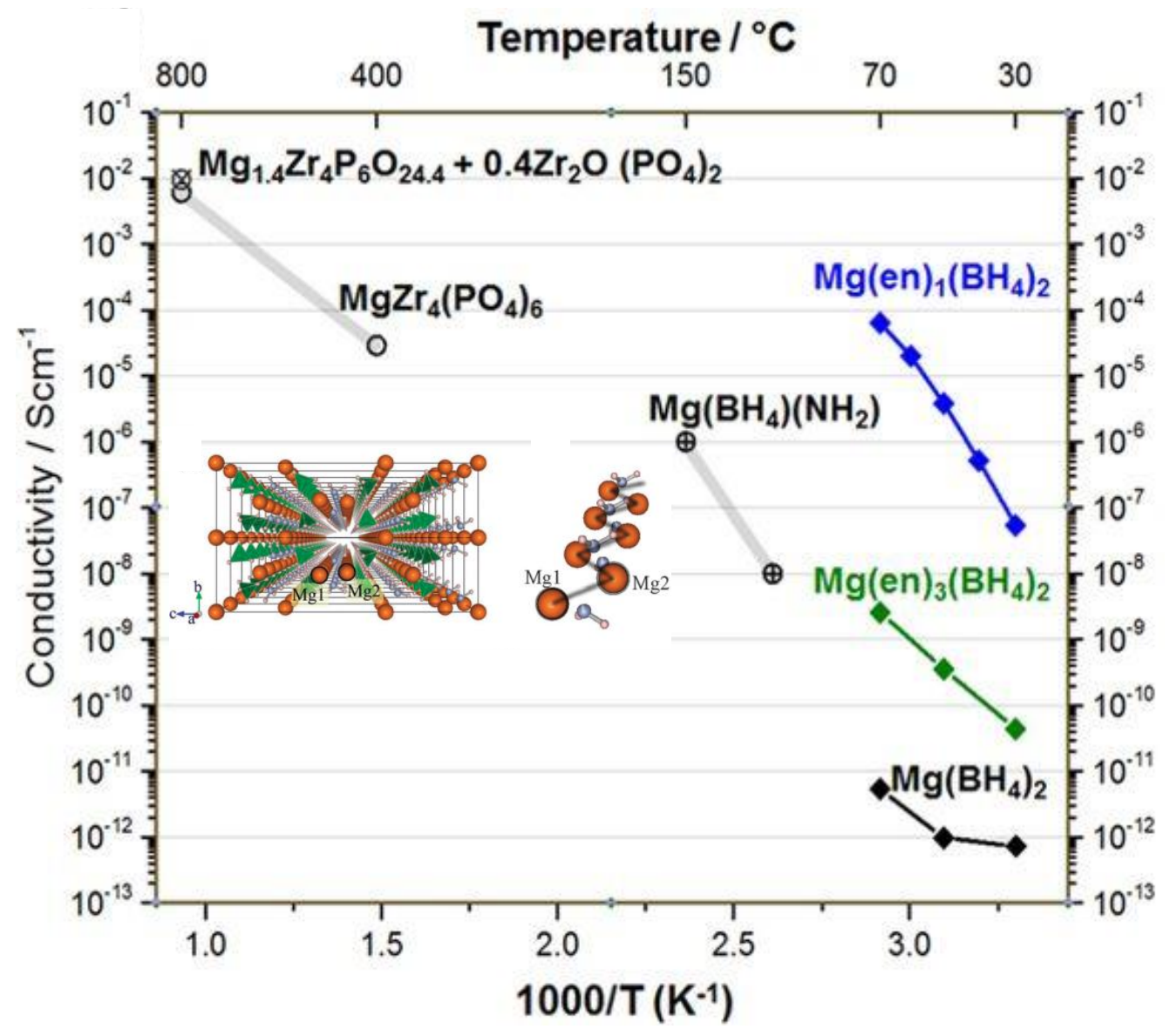

Figure 9. Temperature dependence of ionic conductivity for selected magnesium solid-state electrolytes. The structure of $\mathrm{Mg}\left(\mathrm{BH}_{4}\right)\left(\mathrm{NH}_{2}\right)$ is shown. Reproduced from reference [104] permission from Springer Nature, Copyright 2017.

Higher conductivities at lower temperatures were reported for cis-Mg(en) $\left(\mathrm{BH}_{4}\right)_{2}$, en $=\mathrm{NH}_{2}\left(\mathrm{CH}_{2}\right)_{2} \mathrm{NH}_{2}$ [104]. The material was obtained by the mechanochemical processing of the ethylene diamine and $\mathrm{Mg}\left(\mathrm{BH}_{4}\right)_{2}$ powder mixture. The mobility of $\mathrm{Mg}^{2+}$ ions in cis-Mg(en) $\left(\mathrm{BH}_{4}\right)_{2}$ increased from $5 \times 10^{-8} \mathrm{~S} / \mathrm{cm}$ to $6 \times 10^{-5} \mathrm{~S} / \mathrm{cm}$ in the temperature range $303-343 \mathrm{~K}$ (Figure 9).

Polymer-electrolyte systems typically based on polyethylene oxide (PEO) were also reported for $\mathrm{Mg}$ batteries. The nanocomposite polymer electrolyte based on $\mathrm{PEO}, \mathrm{Mg}\left(\mathrm{BH}_{4}\right)_{2}$ and $\mathrm{MgO}$, allowed for 
reversible $\mathrm{Mg}$ deposition/dissolution with $98 \%$ coulombic efficiency, however the conductivity was not reported [105].

\section{Hydrides' Potential as Stable Solvents: Ionic Liquid Electrolytes}

To eliminate hazards associated with the use of volatile and flammable battery solvents, ionic liquids, which are salts in the liquid state at room temperature, represent an alternative option [106]. Ionic liquids can have high thermal stabilities and appreciable conductivities which make them attractive for use as solvents in batteries. The most successfully used ionic liquids are those for Li and $\mathrm{Na}$ batteries and couple an organic cation (ammonium, phosphonium or pyrrolidinium cations) with a fluorinated anion such as bis(fluorosulfonyl)imide $\left(\left(\mathrm{FSO}_{2}\right)_{2} \mathrm{~N}^{-}, \mathrm{FSI}\right)$ or bis(trifluoromethanosulfonyl) imide $\mathrm{TFSI}^{-}\left(\left(\mathrm{CF}_{3} \mathrm{SO}_{2}\right)_{2} \mathrm{~N}^{-}\right)$[106]. However, one of the key challenges in designing ionic liquids lies in the stability of the electrolyte itself or both the electrolyte/anode and the electrolyte/cathode interphases. For instance, an anion with insufficient oxidative stability can limit the choice of cathode material. Likewise, anions susceptible to decompose under the highly reductive anode environment can partially or fully passive the anode. This has been particularly true in magnesium batteries, where fluorinated anions such as $\mathrm{TFSI}^{-}$passivate the $\mathrm{Mg}$ metal surface thereby prohibiting the use of ionic liquid solvents (unless highly reducing salts/reagents are added) [6]. Recently, as discussed in Section 4, $\mathrm{Mg}$ deposition/stripping was shown possible in electrolytes based on $\mathrm{Mg}\left(\mathrm{BH}_{4}\right)_{2}$ salt and TFSI ${ }^{-}$based ionic liquids $[88,89]$. Reported systems consisted of a pyrrolidinium cation with dangling PEGylated chains [89] or with ether-functionalized ammonium cation $\mathrm{N}_{2(20201) 3}{ }^{+}$[88]. The incorporation of chelating ethereal moieties was inspired by previous studies of enhanced $\mathrm{Mg}\left(\mathrm{BH}_{4}\right)_{2}$ dissociation and performance in ethers with increased number of oxygen electron donors (Section 4) [79,80]. For example, ionic liquids based on methyl polyethylene glycol MPEG 3 PyrTFSI (three ether oxygens) and $\mathrm{MPEG}_{7}$ PyrTFSI were superior to $N$-butyl-N-methylpyrrolidinium BMPyrTFSI [89]. Further studies showed that ionic liquid solutions with small concentrations of $\mathrm{Mg}\left(\mathrm{BH}_{4}\right)_{2}$ (i.e.,18 $\mathrm{mM}$ ) in $0.3 \mathrm{M}$ $\mathrm{Mg}(\mathrm{TFSI})_{2} /$ tetraglyme, $N$-methyl-N-butyl pyrrolidinium TFSI (1:2 molar) allowed for some reversible $\mathrm{Mg}$ deposition/plating (initial coulombic efficiency ca 87\% that degraded with cycling). Interestingly, despite the presence of $\mathrm{Mg}\left(\mathrm{BH}_{4}\right)_{2}$, the anodic stability was reported to be up to $3 \mathrm{~V}$, however it dropped to $c a$ 2.1 V in cycled solutions [107].

In the aforementioned studies, given the use of borohydrides, the true oxidative stabilities of these solutions were low $(<2.5 \mathrm{~V})$. Therefore, to eliminate challenges associated with the use of strongly reducing agents, a new recent alternate approach designed, for the first time, ionic liquids based on closo-borates for $\mathrm{Mg}$ batteries [108]. This was inspired from the high compatibility of the carborate anion as was revealed from the Mg salts analogues (Section 4). In addition, the high oxidative stability and weakly coordinating nature of these anion makes them highly desirable for Li and Na batteries. Consideration of ionic liquids based on closo-borates in energy storage devices in general has been ignored given the very high melting temperature of these salts attributed to the rigid structure of the anion. However, recently, this challenge was overcome by creating ionic liquids which incorporate the highly stable closo-monocarborate anion with ammonium cations decorated with flexible alkoxy ligands $\left(\mathrm{N}_{2(20201) 3}{ }^{+}\right.$and $\left.\mathrm{N}_{4(20201) 3}{ }^{+}\right)$, which compensated for the rigidity of the anion. These ionic liquids were reported to remain in the liquid phase down to $-52{ }^{\circ} \mathrm{C}$, had high conductivity (in the order of $10^{-4} \mathrm{~S} / \mathrm{cm}$ ) and were highly dissociated (Figure 10) [108]. This placed them amongst best performing ionic liquids being considered for batteries. Importantly, they were used to demonstrate reversible $\mathrm{Li}$ and $\mathrm{Mg}$ deposition/stripping thereby marking the introduction of new competent ionic liquids family to energy storage devices [108]. 

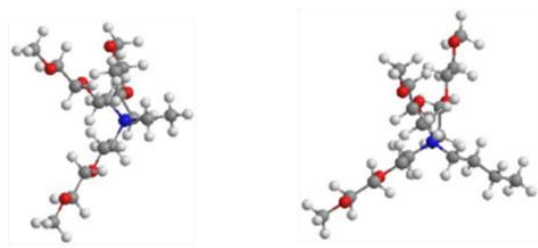

$\left[\mathrm{N}_{2[20201) 3}\right]^{*}$

$\left[\mathrm{N}_{4(20201) 3]^{+}}\right.$

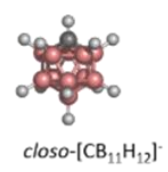

b

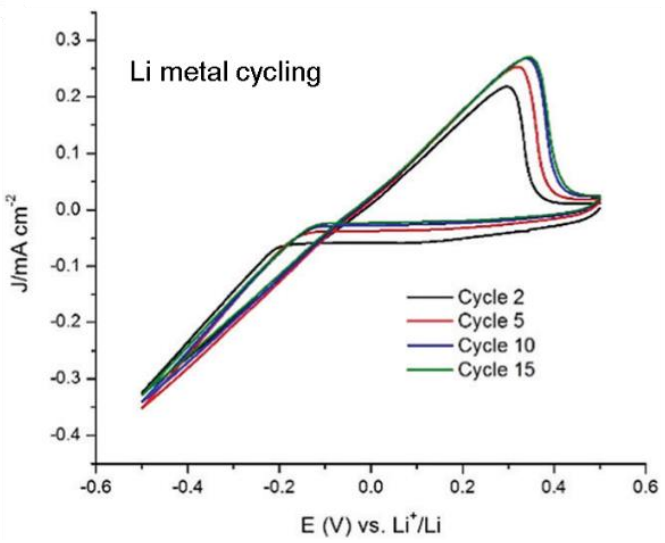

a
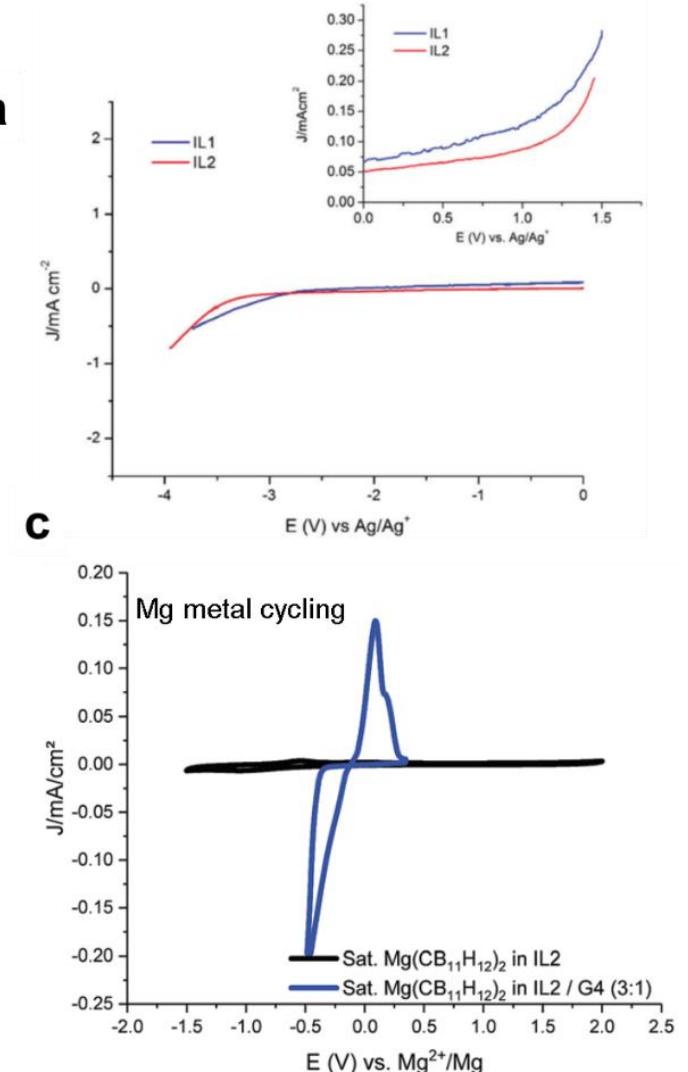

Figure 10. For the closo-carborate ionic liquids (structure shown): (a) Oxidative and reductive stability, (b) and (c) are $\mathrm{Li}$ and $\mathrm{Mg}$ electrochemical deposition/stripping, respectively. Reproduced from reference [108] with permission from the Royal Society of Chemistry, Copyright 2019.

\section{Demonstrations of Hydride Electrolytes in Batteries}

Successful demonstrations of batteries require electrolytes that are not only highly conductive, but that are also highly compatible with both the anode and the cathode. Compatibility means: (1) the electrolyte is stable chemically and electrochemically upon contact with the electrode's components (this includes active materials, other components such as conductive additives, etc.). The consequence of this is the absence of any decomposition products from the electrolyte on the surface of the electrode and (2) the electrolyte is unstable in the environment of the electrode and decomposes generating a surface film on the electrode. These decomposition products however, allow for the passage of the charge carriers (i.e., cations) and importantly serve as a barrier to prevent further decomposition of the electrolyte. The surface layers formed on the anode side are referred to as SEI (Solid Electrolyte Interface) as discussed in Section 4 and those formed on the cathode are called CEIs (Cathode Electrolyte Interfaces). The electrolyte-electrode interactions are complex in nature and highly dependent on the electrode and its components.

The first example of the successful application of hydrides electrolytes in a stably cycling battery cell was reported in a $\mathrm{Mg}$ battery for $\mathrm{Mg}\left(\mathrm{BH}_{4}\right)_{2}-\mathrm{LiBH}_{4} / \mathrm{DME}$ electrolyte with a magnesium anode and a Chevrel phase $\mathrm{Mo}_{6} \mathrm{~S}_{8}$ cathode (Figure 5). The cell was operated at room temperature and delivered the expected performance from the $\mathrm{Mo}_{6} \mathrm{~S}_{8}$ cathode [79]. A follow-up study using a similar battery (rate of C/10), delivered a capacity of $99 \mathrm{mAh} / \mathrm{g}$ during the initial discharge (vs. $129 \mathrm{mAh} / \mathrm{g}$ of the theoretical value) and then retained $90 \%$ of this capacity for over 300 cycles [80].

$\mathrm{LiBH}_{4}$ application as a solid-state electrolyte in all solid-state batteries was first reported in an electrochemical cell with $\mathrm{Li}$ metal anode and $\mathrm{LiCoO}_{2}$ cathode [109]. The battery performance was evaluated at $393 \mathrm{~K}$, which ensured the stability of the highly conductive $\mathrm{LiBH}_{4}$ phase. Due to the nucleophilic nature of borohydrides, parasitic reactions between $\mathrm{LiBH}_{4}$ and $\mathrm{LiCoO}_{2}$ occurred leading to 
high interfacial resistance and significant capacity loss. To mitigate this interaction, amorphous $\mathrm{Li}_{2} \mathrm{PO}_{4}$ was introduced between electrolyte and the cathode and somewhat improved the battery cycling performance; i.e., $97 \%$ of the initial discharge capacity $(89 \mathrm{mAh} / \mathrm{g})$ after 30 cycles. The hydritic nature of the borohydride called for investigating other cathodes wherein stable interface formation between $\mathrm{LiBH}_{4}$ and $\mathrm{TiS}_{2}$ cathode was reported [41,110]. The solid-state battery consisted of TiS 2 cathode, $\mathrm{LiBH}_{4}$ electrolyte and Li anode and was successfully cycled 300 times at $393 \mathrm{~K}$ and a rate of $0.2 \mathrm{C}$. Although, the initial discharge capacity was only $80 \mathrm{mAh} / \mathrm{g}$ (vs. $239 \mathrm{mAh} / \mathrm{g}$ of the theoretical value), at the second cycle the parameter reached $205 \mathrm{mAh} / \mathrm{g}$ with close to $100 \%$ coulombic efficiency. The cell's durability was explained by the chemical/electrochemical oxidation of the borohydride just below the $\mathrm{TiS}_{2}$ surface. This was accompanied by hydrogen release and formation of a new phase, identified to most likely be $\mathrm{Li}_{2} \mathrm{~B}_{12} \mathrm{H}_{12}$. Later studies examined this cathode with other $\mathrm{LiBH}_{4}$ based electrolytes such as $\mathrm{Li}_{4}\left(\mathrm{BH}_{4}\right)_{3} \mathrm{I}$, combined with either $\mathrm{TiS}_{2} / \mathrm{LiBH}_{4}$ or $\mathrm{TiS}_{2} / \mathrm{Li}_{4}\left(\mathrm{BH}_{4}\right)_{3} \mathrm{I}$ composite electrodes [111]. The higher durability of the cell consisting of $\mathrm{TiS}_{2} / \mathrm{Li}_{4}\left(\mathrm{BH}_{4}\right)_{3} \mathrm{I}$ composite electrodes underscored the importance of the high mechanical plasticity in the $\mathrm{I}^{-}$-substituted $\mathrm{LiBH}_{4}$.

The feasibility of lithium-sulfur (Li-S) conversion batteries utilizing a borohydride electrolyte was demonstrated at $393 \mathrm{~K}$ [112]. The Li-S cell delivered $1140 \mathrm{mAh} / \mathrm{g}$ at $0.05 \mathrm{C}$ rate, during the first discharge, which corresponded to $70 \%$ of sulfur utilization ratio. Over the next 45 cycles, the discharge capacity remained as high as $730 \mathrm{mAh} / \mathrm{g}$ with nearly $100 \%$ coulombic efficiency. Further studies using the more $\mathrm{Li}^{+}$conductive electrolytes such as $\mathrm{LiBH}_{4}-$ nanoconfined $\mathrm{LiBH}_{4}$ [113] $\mathrm{LiCl}$ [114] or allowed for lowering the operating temperature of the Li-S cell. The surprising performances of these batteries, despite the highly reactive nature of borohydrides towards $S$, suggest formation of a CEI (Cathode Electrolyte Interface) that is analogous to that observed on $\mathrm{TiS}_{2}$; i.e., closo-borates. In fact, just recently, excellent $\mathrm{Li} / \mathrm{S}$ battery performance was reported in a 7:3 molar $\left[\mathrm{CB}_{9} \mathrm{H}_{10}{ }^{-}: \mathrm{CB}_{11} \mathrm{H}_{12}\right]^{2-} \mathrm{Li}$ salt [70].

The low oxidative stability of the borohydride electrolytes limited the demonstration of high voltage batteries. This was particularly apparent in liquid borohydride electrolytes used in $\mathrm{Mg}$ batteries, which unlike solid-state electrolytes, lacked the presence of the kinetic barriers that could extend the oxidative decomposition onset. However, the high stability of $\mathrm{Mg}\left(\mathrm{CB}_{11} \mathrm{H}_{11}\right)_{2}$ in tetraglyme allowed for cycling the high voltage cathode $\alpha-\mathrm{MnO}_{2}$ (initial discharge capacity of $170 \mathrm{mAh} / \mathrm{g}$, Figure 7). This was the first successful example of a $\mathrm{Mg}$ coin cell operated at voltages close to $3 \mathrm{~V} \mathrm{vs.} \mathrm{Mg}^{2+} / \mathrm{Mg}$ (i.e.,4.2 V vs. $\mathrm{Li}^{+} / \mathrm{Li}$ ) (Figure 7) [94]. On the other hand, one of the best demonstrations of a high voltage solid-state battery $(3 \mathrm{~V})$, was for the $\mathrm{Na}$ metal battery employing $\mathrm{Na}_{2}\left(\mathrm{~B}_{12} \mathrm{H}_{12}\right)_{0.5}\left(\mathrm{~B}_{10} \mathrm{H}_{10}\right)_{0.5}$ electrolyte which was operated for 250 cycles [115]. One key to this successful demonstration was the high oxidative stability of the electrolyte and accomplishing a good contact between the cathode $\left(\mathrm{NaCrO}_{2}\right.$, theoretical capacity of $120 \mathrm{mAh} / \mathrm{g}$ ) and the electrolyte (this was achieved by dissolving the latter in anhydrous methanol and dispersing $\mathrm{NaCrO}_{2}$ into the solution, followed by drying in vacuum and heat treatment at $543 \mathrm{~K}$ in order to recrystallize the electrolyte). A follow-up study utilized isopropanol in order to recrystallize the electrolyte in the cathode at a lower temperature (453 K) [116].

Hydride electrolytes were also examined in batteries employing insertion and alloy anodes in liquid $\mathrm{Mg}$ batteries (i.e., good cycling was reported for Bi anode in a borohydride electrolyte [117]), solid-state lithium ion (i.e., nanostructured $\mathrm{Bi}_{2} \mathrm{Te}_{3} / \mathrm{LiBH}_{4}$ composite [118] or Si with $\mathrm{Li}_{2} \mathrm{~B}_{12} \mathrm{H}_{12}$ [18]) and sodium ion batteries $\left(\mathrm{Na}_{3} \mathrm{Sn}\right.$ anode in $\mathrm{Na}\left(\mathrm{B}_{12} \mathrm{H}_{12}\right)_{0.5}\left(\mathrm{~B}_{10} \mathrm{H}_{10}\right)_{0.5}$ electrolyte) [116]. It is noted that performance losses due to challenges associated with anodes such as Sn and Si occurred and made it difficult to establish the potential advantage of hydrides in these batteries.

\section{Conclusions}

Several decades ago, hydrides were widely investigated as hydrogen storage materials and their potential to electrochemical energy storage devices was limited to the Ni-MH batteries. However, just over a decade ago, this has been altered owing to two key discoveries: First is the discovery of high solid-state ionic conductivity in $\mathrm{LiBH}_{4}$, which opened the doors for designing 
hydrides as highly conducting solid-state electrolytes for Li and $\mathrm{Na}$ batteries. The second was owing to the creation of borohydrides electrolytes that are highly compatible with $\mathrm{Mg}$ metal. This opened a new design space in Mg electrolytes as it resulted in highly competent boron hydrogen-based electrolytes which overcome key challenges and changed several preconceptions about what an ideal electrolyte needs to be like. These advancements have also served to inspire investigating several new families of electrolytes for $\mathrm{Mg}$ batteries.

The high $\mathrm{Li}^{+}$and $\mathrm{Na}^{+}$conductivities in closo-borate solid-state electrolytes allowed for battery demonstrations and have placed them amongst the top performing solid-state electrolytes being investigated. On the other hand, closo-carborate liquid electrolytes have enabled the demonstrations of high voltage $\mathrm{Mg}$ batteries for the first time in battery coin cells.

The journey of hydrides in the field of energy dense batteries is just beginning. Studies of key factors that govern the performances of these materials would be advantageous for future developments. In addition, the high costs associated with closo-borates could represent a barrier towards their practical use and therefore overcoming this challenge would drive the consideration of these materials as future battery electrolytes.

Funding: Funding for meeting costs associated with the preparation of this review was provided by Toyota Motor Corporation.

Conflicts of Interest: The author declares no conflict of interest.

\section{References}

1. Tarascon, J.M.; Armand, M. Issues and challenges facing rechargeable lithium batteries. Nature 2001, 414, 359-367. [CrossRef] [PubMed]

2. Choi, J.W.; Aurbach, D. Promise and reality of post-lithium-ion batteries with high energy densities. Nat. Rev. Mater. 2016, 1, 16013. [CrossRef]

3. Zhang, Z.; Shao, Y.; Lotsch, B.; Hu, Y.-S.; Li, H.; Janek, J.; Nazar, L.F.; Nan, C.-W.; Maier, J.; Armand, M.; et al. New horizons for inorganic solid state ion conductors. Energy Environ. Sci. 2018, 11, 1945-1976. [CrossRef]

4. Wang, Q.; Jiang, L.; Yu, Y.; Sun, J. Progress of enhancing the safety of lithium ion battery from the electrolyte aspect. Nano Energy 2019, 55, 93-114. [CrossRef]

5. Kato, Y.; Hori, S.; Saito, T.; Suzuki, K.; Hirayama, M.; Mitsui, A.; Yonemura, M.; Iba, H.; Kanno, R. High-power all-solid-state batteries using sulfide superionic conductors. Nat. Energy 2016, 1, 16030. [CrossRef]

6. Mohtadi, R.; Mizuno, F. Magnesium batteries: Current state of the art, issues and future perspectives. Beilstein J. Nanotechnol. 2014, 5, 1291-1311. [CrossRef]

7. Ponrouch, A.; Palacin, M.R. On the road toward calcium-based batteries. Curr. Opin. Electrochem. 2018, 9, 1-7. [CrossRef]

8. Mohtadi, R.; Orimo, S.-I. The renaissance of hydrides as energy materials. Nat. Rev. Mater. 2016, 2, 16091. [CrossRef]

9. Tutusaus, O.; Mohtadi, R. Paving the Way towards Highly Stable and Practical Electrolytes for Rechargeable Magnesium Batteries. ChemElectroChem 2015, 2, 51-57. [CrossRef]

10. Boukamp, B.A.; Huggins, R.A. Ionic-Conductivity in Lithium Imide. Phys. Lett. A 1979, 72, 464-466. [CrossRef]

11. Matsuo, M.; Nakamori, Y.; Orimo, S.; Maekawa, H.; Takamura, H. Lithium superionic conduction in lithium borohydride accompanied by structural transition. Appl. Phys. Lett. 2007, 91, 224103. [CrossRef]

12. Nakamori, Y.; Orimo, S.; Tsutaoka, T. Dehydriding reaction of metal hydrides and alkali borohydrides enhanced by microwave irradiation. Appl. Phys. Lett. 2006, 88, 112104. [CrossRef]

13. Matsuo, M.; Orimo, S. Lithium Fast-Ionic Conduction in Complex Hydrides: Review and Prospects. Adv. Energy Mater. 2011, 1, 161-172. [CrossRef]

14. Buchter, F.; Lodziana, Z.; Mauron, P.; Remhof, A.; Friedrichs, O.; Borgschulte, A.; Zuttel, A.; Sheptyakov, D.; Strassle, T.; Ramirez-Cuesta, A.J. Dynamical properties and temperature induced molecular disordering of LiBH4 and LiBD4. Phys. Rev. B 2008, 78, 094302. [CrossRef] 
15. Remhof, A.; Lodziana, Z.; Martelli, P.; Friedrichs, O.; Zuttel, A.; Skripov, A.V.; Embs, J.P.; Strassle, T. Rotational motion of $\mathrm{BH} 4$ units in $\mathrm{MBH} 4(\mathrm{M}=\mathrm{Li}, \mathrm{Na}, \mathrm{K})$ from quasielastic neutron scattering and density functional calculations. Phys. Rev. B 2010, 81, 214304. [CrossRef]

16. Asakura, R.; Duchêne, L.; Kühnel, R.-S.; Remhof, A.; Hagemann, H.; Battaglia, C. Electrochemical Oxidative Stability of Hydroborate-Based Solid-State Electrolytes. ACS Appl. Energy Mater. 2019, 2, 6924-6930. [CrossRef]

17. Maekawa, H.; Matsuo, M.; Takamura, H.; Ando, M.; Noda, Y.; Karahashi, T.; Orimo, S.I. Halide-Stabilized LiBH4, a Room-Temperature Lithium Fast-Ion Conductor. J. Am. Chem. Soc. 2009, 131, 894-895. [CrossRef]

18. Oguchi, H.; Matsuo, M.; Hummelshoj, J.S.; Vegge, T.; Norskov, J.K.; Sato, T.; Miura, Y.; Takamura, H.; Maekawa, H.; Orimo, S. Experimental and computational studies on structural transitions in the LiBH4-LiI pseudobinary system. Appl. Phys. Lett. 2009, 94, 141912. [CrossRef]

19. Miyazaki, R.; Karahashi, T.; Kumatani, N.; Noda, Y.; Ando, M.; Takamura, H.; Matsuo, M.; Orimo, S.; Maekawa, H. Room temperature lithium fast-ion conduction and phase relationship of LiI stabilized LiBH4. Solid State Ion. 2011, 192, 143-147. [CrossRef]

20. Matsuo, M.; Remhof, A.; Martelli, P.; Caputo, R.; Ernst, M.; Miura, Y.; Sato, T.; Oguchi, H.; Maekawa, H.; Takamura, H.; et al. Complex Hydrides with (BH4)(-) and (NH2)(-) Anions as New Lithium Fast-Ion Conductors. J. Am. Chem. Soc. 2009, 131, 16389-16391. [CrossRef]

21. Yan, Y.; Kühnel, R.-S.; Remhof, A.; Duchêne, L.; Reyes, E.C.; Rentsch, D.; Łodziana, Z.; Battaglia, C. A Lithium Amide-Borohydride Solid-State Electrolyte with Lithium-Ion Conductivities Comparable to Liquid Electrolytes. Adv. Energy Mater. 2017, 7, 1700294. [CrossRef]

22. Ley, M.B.; Ravnsbæk, D.B.; Filinchuk, Y.; Lee, Y.-S.; Janot, R.; Cho, Y.W.; Skibsted, J.; Jensen, T.R. LiCe(BH4)3Cl, a New Lithium-Ion Conductor and Hydrogen Storage Material with Isolated Tetranuclear Anionic Clusters. Chem. Mater. 2012, 24, 1654-1663. [CrossRef]

23. GharibDoust, S.P.; Brighi, M.; Sadikin, Y.; Ravnsbaek, D.B.; Cerny, R.; Skibsted, J.; Jensen, T.R. Synthesis, Structure, and Li-Ion Conductivity of LiLa(BH4)(3)X, X = Cl, Br, I.J. Phys. Chem. C 2017, 121, 19010-19021. [CrossRef]

24. Lee, Y.S.; Filinchuk, Y.; Lee, H.S.; Suh, J.Y.; Kim, J.W.; Yu, J.S.; Cho, Y.W. On the Formation and the Structure of the First Bimetallic Borohydride Borate, LiCa3(BH4)(BO3)(2). J. Phys. Chem. C 2011, 115, 10298-10304. [CrossRef]

25. Didelot, E.; Cerny, R. Ionic conduction in bimetallic borohydride borate, LiCa3(BH4)(BO3)(2). Solid State Ion. 2017, 305, 16-22. [CrossRef]

26. Ngene, P.; Adelhelm, P.; Beale, A.M.; de Jong, K.P.; de Jongh, P.E. LiBH4/SBA-15 Nanocomposites Prepared by Melt Infiltration under Hydrogen Pressure: Synthesis and Hydrogen Sorption Properties. J. Phys. Chem. C 2010, 114, 6163-6168. [CrossRef]

27. Blanchard, D.; Nale, A.; Sveinbjornsson, D.; Eggenhuisen, T.M.; Verkuijlen, M.H.; Vegge, T.; Kentgens, A.P.M.; de Jongh, P.E. Nanoconfined LiBH4 as a Fast Lithium Ion Conductor. Adv. Funct. Mater. 2015, 25, 184-192. [CrossRef]

28. Verdal, N.; Udovic, T.J.; Rush, J.J.; Liu, X.F.; Majzoub, E.H.; Vajo, J.J.; Gross, A.F. Dynamical Perturbations of Tetrahydroborate Anions in LiBH4 due to Nanoconfinement in Controlled-Pore Carbon Scaffolds. J. Phys. Chem. C 2013, 117, 17983-17995. [CrossRef]

29. Choi, Y.S.; Lee, Y.S.; Choi, D.J.; Chae, K.H.; Oh, K.H.; Cho, Y.W. Enhanced Li Ion Conductivity in LiBH4-Al2O3 Mixture via Interface Engineering. J. Phys. Chem. C 2017, 121, 26209-26215. [CrossRef]

30. Teprovich, J.A.; Colon-Mercado, H.R.; Ward, P.A.; Peters, B.; Giri, S.; Zhou, J.; Greenway, S.; Compton, R.N.; Jena, P.; Zidan, R. Experimental and Theoretical Analysis of Fast Lithium Ionic Conduction in a LiBH4-C-60 Nanocomposite. J. Phys. Chem. C 2014, 118, 21755-21761. [CrossRef]

31. Unemoto, A.; Wu, H.; Udovic, T.J.; Matsuo, M.; Ikeshoji, T.; Orimo, S. Fast lithium-ionic conduction in a new complex hydride-sulphide crystalline phase. Chem. Commun. 2016, 52, 564-566. [CrossRef]

32. Yamauchi, A.; Sakuda, A.; Hayashi, A.; Tatsumisago, M. Preparation and ionic conductivities of $(100-x)(0.75 \mathrm{Li}(2) \mathrm{S}$ center dot $0.25 \mathrm{P}(2) \mathrm{S}(5))$ center dot $\mathrm{xLiBH}(4)$ glass electrolytes. J. Power Sources 2013, 244, 707-710. [CrossRef]

33. El Kharbachi, A.; Hu, Y.; Yoshida, K.; Vajeeston, P.; Kim, S.; Sorby, M.H.; Orimo, S.; Fjellvag, H.; Hauback, B.C. Lithium ionic conduction in composites of $\mathrm{Li}(\mathrm{BH} 4)(0.75) \mathrm{I}-0.25$ and amorphous $0.75 \mathrm{Li}(2) \mathrm{S}$ center dot 0.25P(2)S(5) for battery applications. Electrochim. Acta 2018, 278, 332-339. [CrossRef] 
34. Sveinbjörnsson, D.; Blanchard, D.; Myrdal, J.S.G.; Younesi, R.; Viskinde, R.; Riktor, M.D.; Norby, P.; Vegge, T. Ionic conductivity and the formation of cubic $\mathrm{CaH} 2$ in the $\mathrm{LiBH} 4-\mathrm{Ca}(\mathrm{BH} 4) 2$ composite. J. Solid State Chem. 2014, 211, 81-89. [CrossRef]

35. Xiang, M.; Zhang, Y.; Zhan, L.; Zhu, Y.; Guo, X.; Chen, J.; Wang, Z.; Li, L. Study on xLiBH4-NaBH4 (x = 1.6, 2.3, and 4) composites with enhanced lithium ionic conductivity. J. Alloy. Compd. 2017, 729, $936-941$. [CrossRef]

36. López-Aranguren, P.; Berti, N.; Dao, A.H.; Zhang, J.; Cuevas, F.; Latroche, M.; Jordy, C. An all-solid-state metal hydride-Sulfur lithium-ion battery. J. Power Sources 2017, 357, 56-60. [CrossRef]

37. Xiang, M.; Zhang, Y.; Zhu, Y.; Guo, X.; Chen, J.; Li, L. Ternary LiBH4-NaBH4-MgH2 composite as fast ionic conductor. Solid State Ion. 2018, 324, 109-113. [CrossRef]

38. Xiang, M.; Zhang, Y.; Lin, H.; Zhu, Y.; Guo, X.; Chen, J.; Li, L. LiBH4-NaX (X = Cl, I) composites with enhanced lithium ionic conductivity. J. Alloy. Compd. 2018, 764, 307-313. [CrossRef]

39. Zhang, T.; Wang, Y.; Song, T.; Miyaoka, H.; Shinzato, K.; Miyaoka, H.; Ichikawa, T.; Shi, S.; Zhang, X.; Isobe, S.; et al. Ammonia, a Switch for Controlling High Ionic Conductivity in Lithium Borohydride Ammoniates. Joule 2018, 2, 1522-1533. [CrossRef]

40. Matsuo, M.; Kuromoto, S.; Sato, T.; Oguchi, H.; Takamura, H.; Orimo, S. Sodium ionic conduction in complex hydrides with [BH4](-) and [NH2](-) anions. Appl. Phys. Lett. 2012, 100, 203904. [CrossRef]

41. Unemoto, A.; Matsuo, M.; Orimo, S. Complex Hydrides for Electrochemical Energy Storage. Adv. Funct. Mater. 2014, 24, 2267-2279. [CrossRef]

42. Matsuo, M.; Oguchi, H.; Sato, T.; Takamura, H.; Tsuchida, E.; Ikeshoji, T.; Orimo, S. Sodium and magnesium ionic conduction in complex hydrides. J. Alloy. Compd. 2013, 580, S98-S101. [CrossRef]

43. Oguchi, H.; Matsuo, M.; Sato, T.; Takamura, H.; Maekawa, H.; Kuwano, H.; Orimo, S. Lithium-ion conduction in complex hydrides $\mathrm{LiAlH}(4)$ and $\mathrm{Li}(3) \mathrm{AlH}(6) . J$. Appl. Phys. 2010, 107, 096104. [CrossRef]

44. Li, W.; Wu, G.T.; Xiong, Z.T.; Feng, Y.P.; Chen, P. Li+ ionic conductivities and diffusion mechanisms in Li-based imides and lithium amide. Phys. Chem. Chem. Phys. 2012, 14, 1596-1606. [CrossRef] [PubMed]

45. Rijssenbeek, J.; Gao, Y.; Hanson, J.; Huang, Q.; Jones, C.; Toby, B. Crystal structure determination and reaction pathway of amide-hydride mixtures. J. Alloy. Compd. 2008, 454, 233-244. [CrossRef]

46. Wu, G.T.; Xiong, Z.T.; Liu, T.; Liu, Y.F.; Hu, J.J.; Chen, P.; Feng, Y.P.; Wee, A.T.S. Synthesis and characterization of a new ternary imide-Li2Ca(NH)(2). Inorg. Chem. 2007, 46, 517-521. [CrossRef] [PubMed]

47. Martelli, P.; Remhof, A.; Borgschulte, A.; Ackermann, R.; Strassle, T.; Embs, J.P.; Ernst, M.; Matsuo, M.; Orimo, S.I.; Zuttel, A. Rotational Motion in LiBH4/LiI Solid Solutions. J. Phys. Chem. A 2011, 115, 5329-5334. [CrossRef]

48. Skripov, A.V.; Soloninin, A.V.; Ley, M.B.; Jensen, T.R.; Filinchuk, Y. Nuclear Magnetic Resonance Studies of BH4 Reorientations and Li Diffusion in LiLa(BH4)(3)Cl. J. Phys. Chem. C 2013, 117, 14965-14972. [CrossRef]

49. Lee, Y.-S.; Ley, M.B.; Jensen, T.R.; Cho, Y.W. Lithium Ion Disorder and Conduction Mechanism in LiCe(BH4)3Cl. J. Phys. Chem. C 2016, 120, 19035-19042. [CrossRef]

50. Jansen, M. Volume Effect or Paddle-Wheel Mechanism-Fast Alkali-Metal Ionic-Conduction in Solids with Rotationally Disordered Complex Anions. Angew. Chem. Int. Ed. Engl. 1991, 30, 1547-1558. [CrossRef]

51. Verdal, N.; Udovic, T.J.; Rush, J.J.; Wu, H.; Skripov, A.V. Evolution of the Reorientational Motions of the Tetrahydroborate Anions in Hexagonal LiBH4-Lil Solid Solution by High-Q Quasielastic Neutron Scattering. J. Phys. Chem. C 2013, 117, 12010-12018. [CrossRef]

52. Orimo, S.-I.; Nakamori, Y.; Eliseo, J.R.; Züttel, A.; Jensen, C.M. Complex Hydrides for Hydrogen Storage. Chem. Rev. 2007, 107, 4111-4132. [CrossRef] [PubMed]

53. Paskevicius, M.; Pitt, M.P.; Brown, D.H.; Sheppard, D.A.; Chumphongphan, S.; Buckley, C.E. First-order phase transition in the Li2B12H12 system. Phys. Chem. Chem. Phys. 2013, 15, 15825-15828. [CrossRef] [PubMed]

54. Skripov, A.V.; Babanova, O.A.; Soloninin, A.V.; Stavila, V.; Verdal, N.; Udovic, T.J.; Rush, J.J. Nuclear Magnetic Resonance Study of Atomic Motion in A2B12H12 (A = Na, K, Rb, Cs): Anion Reorientations and Na+ Mobility. J. Phys. Chem. C 2013, 117, 25961-25968. [CrossRef]

55. Udovic, T.J.; Matsuo, M.; Unemoto, A.; Verdal, N.; Stavila, V.; Skripov, A.V.; Rush, J.J.; Takamura, H.; Orimo, S. Sodium superionic conduction in Na2B12H12. Chem. Commun. 2014, 50, 3750-3752. [CrossRef] 
56. Udovic, T.J.; Matsuo, M.; Tang, W.S.; Wu, H.; Stavila, V.; Soloninin, A.V.; Skoryunov, R.V.; Babanova, O.A.; Skripov, A.V.; Rush, J.J.; et al. Exceptional Superionic Conductivity in Disordered Sodium Decahydro-closo-decaborate. Adv. Mater. 2014, 26, 7622-7626. [CrossRef]

57. Varley, J.B.; Kweon, K.; Mehta, P.; Shea, P.; Heo, T.W.; Udovic, T.J.; Stavila, V.; Wood, B.C. Understanding Ionic Conductivity Trends in Polyborane Solid Electrolytes from Ab Initio Molecular Dynamics. ACS Energy Lett. 2017, 2, 250-255. [CrossRef]

58. Kweon, K.E.; Varley, J.B.; Shea, P.; Adelstein, N.; Mehta, P.; Heo, T.W.; Udovic, T.J.; Stavila, V.; Wood, B.C. Structural, Chemical, and Dynamical Frustration: Origins of Superionic Conductivity in closo-Borate Solid Electrolytes. Chem. Mater. 2017, 29, 9142-9153. [CrossRef]

59. Sadikin, Y.; Brighi, M.; Schouwink, P.; Cerny, R. Superionic Conduction of Sodium and Lithium in Anion-Mixed Hydroborates Na3BH4B12H12 and (Li0.7Na0.3)(3)BH4B12H12. Adv. Energy Mater. 2015, 5, 1501016. [CrossRef]

60. He, L.; Li, H.-W.; Nakajima, H.; Tumanov, N.; Filinchuk, Y.; Hwang, S.-J.; Sharma, M.; Hagemann, H.; Akiba, E. Synthesis of a Bimetallic Dodecaborate LiNaB12H12 with Outstanding Superionic Conductivity. Chem. Mater. 2015, 27, 5483-5486. [CrossRef]

61. Duchene, L.; Kuhnel, R.S.; Rentsch, D.; Remhof, A.; Hagemann, H.; Battaglia, C. A highly stable sodium solid-state electrolyte based on a dodeca/deca-borate equimolar mixture. Chem. Commun. 2017, 53, 4195-4198. [CrossRef] [PubMed]

62. Yoshida, K.; Sato, T.; Unemoto, A.; Matsuo, M.; Ikeshoji, T.; Udovic, T.J.; Orimo, S. Fast sodium ionic conduction in Na2B10H10-Na2B12H12 pseudo-binary complex hydride and application to a bulk-type all-solid-state battery. Appl. Phys. Lett. 2017, 110, 103901. [CrossRef]

63. Teprovich, J.A.; Colon-Mercado, H.; Washington Ii, A.L.; Ward, P.A.; Greenway, S.; Missimer, D.M.; Hartman, H.; Velten, J.; Christian, J.H.; Zidan, R. Bi-functional Li2B12H12 for energy storage and conversion applications: Solid-state electrolyte and luminescent down-conversion dye. J. Mater. Chem. A 2015, 3, 22853-22859. [CrossRef]

64. Tang, W.S.; Yoshida, K.; Soloninin, A.V.; Skoryunov, R.V.; Babanova, O.A.; Skripov, A.V.; Dimitrievska, M.; Stavila, V.; Orimo, S.-I.; Udovic, T.J. Stabilizing Superionic-Conducting Structures via Mixed-Anion Solid Solutions of Monocarba-closo-borate Salts. ACS Energy Lett. 2016, 1, 659-664. [CrossRef]

65. Tang, W.S.; Matsuo, M.; Wu, H.; Stavila, V.; Unemoto, A.; Orimo, S.-I.; Udovic, T.J. Stabilizing lithium and sodium fast-ion conduction in solid polyhedral-borate salts at device-relevant temperatures. Energy Storage Mater. 2016, 4, 79-83. [CrossRef]

66. Kim, S.; Toyama, N.; Oguchi, H.; Sato, T.; Takagi, S.; Ikeshoji, T.; Orimo, S.-I. Fast Lithium-Ion Conduction in Atom-Deficient closo-Type Complex Hydride Solid Electrolytes. Chem. Mater. 2018, 30, 386-391. [CrossRef]

67. Tang, W.S.; Unemoto, A.; Zhou, W.; Stavila, V.; Matsuo, M.; Wu, H.; Orimo, S.-I.; Udovic, T.J. Unparalleled lithium and sodium superionic conduction in solid electrolytes with large monovalent cage-like anions. Energy Environ. Sci. 2015, 8, 3637-3645. [CrossRef]

68. Dimitrievska, M.; Shea, P.; Kweon, K.E.; Bercx, M.; Varley, J.B.; Tang, W.S.; Skripov, A.V.; Stavila, V.; Udovic, T.J.; Wood, B.C. Carbon Incorporation and Anion Dynamics as Synergistic Drivers for Ultrafast Diffusion in Superionic LiCB11H12 and NaCB11H12. Adv. Energy Mater. 2018, 8, 1703422. [CrossRef]

69. Tang, W.S.; Matsuo, M.; Wu, H.; Stavila, V.; Zhou, W.; Talin, A.A.; Soloninin, A.V.; Skoryunov, R.V.; Babanova, O.A.; Skripov, A.V.; et al. Liquid-like Ionic Conduction in Solid Lithium and Sodium Monocarba-closo-decaborates near or at Room Temperature. Adv. Energy Mater. 2016, 6, 1502237. [CrossRef]

70. Kim, S.; Oguchi, H.; Toyama, N.; Sato, T.; Takagi, S.; Otomo, T.; Arunkumar, D.; Kuwata, N.; Kawamura, J.; Orimo, S.-I. A complex hydride lithium superionic conductor for high-energy-density all-solid-state lithium metal batteries. Nat. Commun. 2019, 10, 1081. [CrossRef]

71. Brighi, M.; Murgia, F.; Łodziana, Z.; Schouwink, P.; Wołczyk, A.; Cerny, R. A mixed anion hydroborate/carba-hydroborate as a room temperature Na-ion solid electrolyte. J. Power Sources 2018, 404,7-12. [CrossRef]

72. Tang, W.S.; Dimitrievska, M.; Stavila, V.; Zhou, W.; Wu, H.; Talin, A.A.; Udovic, T.J. Order-Disorder Transitions and Superionic Conductivity in the Sodium nido-Undeca(carba)borates. Chem. Mater. 2017, 29, 10496-10509. [CrossRef]

73. Yan, Y.; Rentsch, D.; Battaglia, C.; Remhof, A. Synthesis, stability and Li-ion mobility of nanoconfined Li2B12H12. Dalton Trans. 2017, 46, 12434-12437. [CrossRef] [PubMed] 
74. Hansen, B.R.S.; Paskevicius, M.; Jørgensen, M.; Jensen, T.R. Halogenated Sodium-closo-Dodecaboranes as Solid-State Ion Conductors. Chem. Mater. 2017, 29, 3423-3430. [CrossRef]

75. Sharma, M.; Sethio, D.; Lawson Daku, L.M.; Hagemann, H. Theoretical Study of Halogenated B12HnX(12-n)2(X=F, Cl, Br). J. Phys. Chem. A 2019, 123, 1807-1813. [CrossRef]

76. Yoo, H.D.; Shterenberg, I.; Gofer, Y.; Gershinsky, G.; Pour, N.; Aurbach, D. Mg rechargeable batteries: An on-going challenge. Energy Environ. Sci. 2013, 6, 2265-2279. [CrossRef]

77. Aurbach, D.; Cohen, Y.; Moshkovich, M. The Study of Reversible Magnesium Deposition by In Situ Scanning Tunneling Microscopy. Electrochem. Solid-State Lett. 2001, 4, A113-A116. [CrossRef]

78. Dong, H.; Tutusaus, Y.L.O.; Mohtadi, R.; Zhang, Y.; Hao, F.; Yao, Y. Directing Mg-storage chemistry in organic polymers towards high-energy Mg batteries. Joule 2018, 3, 782-793. [CrossRef]

79. Mohtadi, R.; Matsui, M.; Arthur, T.S.; Hwang, S.J. Magnesium borohydride: From hydrogen storage to magnesium battery. Angew. Chem. Int. Ed. 2012, 51, 9780-9783. [CrossRef]

80. Shao, Y.; Liu, T.; Li, G.; Gu, M.; Nie, Z.; Engelhard, M.; Xiao, J.; Lv, D.; Wang, C.; Zhang, J.-G.; et al. Coordination Chemistry in magnesium battery electrolytes: How ligands affect their performance. Sci. Reports 2013, 3, 3130. [CrossRef]

81. Tuerxun, F.; Abulizi, Y.; NuLi, Y.N.; Su, S.J.; Yang, J.; Wang, J.L. High concentration magnesium borohydride/tetraglyme electrolyte for rechargeable magnesium batteries. J. Power Sources 2015, 276, $255-261$. [CrossRef]

82. Samuel, D.; Steinhauser, C.; Smith, J.G.; Kaufman, A.; Radin, M.D.; Naruse, J.; Hiramatsu, H.; Siegel, D.J. Ion Pairing and Diffusion in Magnesium Electrolytes Based on Magnesium Borohydride. ACS Appl. Mater. Interfaces 2017, 9, 43755-43766. [CrossRef] [PubMed]

83. Deetz, J.D.; Cao, F.; Wang, Q.; Sun, H. Exploring the Liquid Structure and Ion Formation in Magnesium Borohydride Electrolyte Using Density Functional Theory. J. Electrochem. Soc. 2018, 165, A61-A70. [CrossRef]

84. Orikasa, Y.; Masese, T.; Koyama, Y.; Mori, T.; Hattori, M.; Yamamoto, K.; Okado, T.; Huang, Z.-D.; Minato, T.; Tassel, C.; et al. High energy density rechargeable magnesium battery using earth-abundant and non-toxic elements. Sci. Rep. 2014, 4, 5622. [CrossRef]

85. Sa, N.; Rajput, N.N.; Wang, H.; Key, B.; Ferrandon, M.; Srinivasan, V.; Persson, K.A.; Burrell, A.K.; Vaughey, J.T. Concentration dependent electrochemical properties and structural analysis of a simple magnesium electrolyte: Magnesium bis(trifluoromethane sulfonyl)imide in diglyme. RSC Adv. 2016, 6, 113663-113670. [CrossRef]

86. Rajput, N.N.; Qu, X.; Sa, N.; Burrell, A.K.; Persson, K.A. The Coupling between Stability and Ion Pair Formation in Magnesium Electrolytes from First-Principles Quantum Mechanics and Classical Molecular Dynamics. J. Am. Chem. Soc. 2015, 137, 3411-3420. [CrossRef]

87. Hu, J.Z.; Rajput, N.N.; Wan, C.; Shao, Y.; Deng, X.; Jaegers, N.R.; Hu, M.; Chen, Y.; Shin, Y.; Monk, J.; et al. $25 \mathrm{Mg}$ NMR and computational modeling studies of the solvation structures and molecular dynamics in magnesium based liquid electrolytes. Nano Energy 2018, 46, 436-446. [CrossRef]

88. Kar, M.; Ma, Z.; Azofra, L.M.; Chen, K.; Forsyth, M.; MacFarlane, D.R. Ionic liquid electrolytes for reversible magnesium electrochemistry. Chem. Commun. 2016, 52, 4033-4036. [CrossRef]

89. Watkins, T.; Kumar, A.; Buttry, D.A. Designer Ionic Liquids for Reversible Electrochemical Deposition/Dissolution of Magnesium. J. Am. Chem. Soc. 2016, 138, 641-650. [CrossRef]

90. Xu, H.; Zhang, Z.; Li, J.; Qiao, L.; Lu, C.; Tang, K.; Dong, S.; Ma, J.; Liu, Y.; Zhou, X.; et al. Multifunctional Additives Improve the Electrolyte Properties of Magnesium Borohydride Toward Magnesium-Sulfur Batteries. ACS Appl. Mater. Interfaces 2018, 10, 23757-23765. [CrossRef]

91. Hebié, S.; Ngo, H.P.K.; Leprêtre, J.-C.; Iojoiu, C.; Cointeaux, L.; Berthelot, R.; Alloin, F. Electrolyte Based on Easily Synthesized, Low Cost Triphenolate-Borohydride Salt for High Performance Mg(TFSI)2-Glyme Rechargeable Magnesium Batteries. ACS Appl. Mater. Interfaces 2017, 9, 28377-28385. [CrossRef] [PubMed]

92. Wang, D.; Gao, X.; Chen, Y.; Jin, L.; Kuss, C.; Bruce, P.G. Plating and stripping calcium in an organic electrolyte. Nat. Mater. 2017, 17, 16. [CrossRef] [PubMed]

93. Carter, T.J.; Mohtadi, R.; Arthur, T.S.; Mizuno, F.; Zhang, R.; Shirai, S.; Kampf, J.W. Boron Clusters as Highly Stable Magnesium-Battery Electrolytes. Angew. Chem. Int. Ed. 2014, 53, 3173-3177. [CrossRef] [PubMed]

94. Tutusaus, O.; Mohtadi, R.; Arthur, T.S.; Mizuno, F.; Nelson, E.G.; Sevryugina, Y.V. An Efficient Halogen-Free Electrolyte for Use in Rechargeable Magnesium Batteries. Angew. Chem. Int. Ed. 2015, 54, 7900-7904. [CrossRef] [PubMed] 
95. Hahn, N.T.; Seguin, T.J.; Lau, K.-C.; Liao, C.; Ingram, B.J.; Persson, K.A.; Zavadil, K.R. Enhanced Stability of the Carba-closo-dodecaborate Anion for High-Voltage Battery Electrolytes through Rational Design. J. Am. Chem. Soc. 2018, 140, 11076-11084. [CrossRef]

96. Song, J.; Sahadeo, E.; Noked, M.; Lee, S.B. Mapping the Challenges of Magnesium Battery. J. Phys. Chem. Lett. 2016, 7, 1736-1749. [CrossRef]

97. Xu, K. Electrolytes and Interphases in Li-Ion Batteries and Beyond. Chem. Rev. 2014, 114, 11503-11618. [CrossRef]

98. Xu, K. Nonaqueous Liquid Electrolytes for Lithium-Based Rechargeable Batteries. Chem. Rev. 2004, 104, 4303-4418. [CrossRef]

99. Arthur, T.S.; Glans, P.-A.; Singh, N.; Tutusaus, O.; Nie, K.; Liu, Y.-S.; Mizuno, F.; Guo, J.; Alsem, D.H.; Salmon, N.J.; et al. Interfacial Insight from Operando XAS/TEM for Magnesium Metal Deposition with Borohydride Electrolytes. Chem. Mater. 2017, 29, 7183-7188. [CrossRef]

100. Chang, J.; Haasch, R.T.; Kim, J.; Spila, T.; Braun, P.V.; Gewirth, A.A.; Nuzzo, R.G. Synergetic Role of Li+ during $\mathrm{Mg}$ Electrodeposition/Dissolution in Borohydride Diglyme Electrolyte Solution: Voltammetric Stripping Behaviors on a Pt Microelectrode Indicative of Mg-Li Alloying and Facilitated Dissolution. ACS Appl. Mater. Interfaces 2015, 7, 2494-2502. [CrossRef]

101. Tutusaus, O.; Mohtadi, R.; Singh, N.; Arthur, T.S.; Mizuno, F. Study of Electrochemical Phenomena Observed at the Mg Metal/Electrolyte Interface. ACS Energy Lett. 2017, 2, 224-229. [CrossRef]

102. Singh, N.; Arthur, T.S.; Tutusaus, O.; Li, J.; Kisslinger, K.; Xin, H.L.; Stach, E.A.; Fan, X.; Mohtadi, R. Achieving High Cycling Rates via In Situ Generation of Active Nanocomposite Metal Anodes. ACS Appl. Energy Mater. 2018, 1, 4651-4661. [CrossRef]

103. Higashi, S.; Miwa, K.; Aoki, M.; Takechi, K. A novel inorganic solid state ion conductor for rechargeable Mg batteries. Chem. Commun. 2014, 50, 1320-1322. [CrossRef] [PubMed]

104. Roedern, E.; Kuhnel, R.S.; Remhof, A.; Battaglia, C. Magnesium Ethylenediamine Borohydride as Solid-State Electrolyte for Magnesium Batteries. Sci. Rep. 2017, 7, 46189. [CrossRef] [PubMed]

105. Shao, Y.Y.; Rajput, N.N.; Hu, J.Z.; Hu, M.; Liu, T.B.; Wei, Z.H.; Gu, M.; Deng, X.C.; Xu, S.C.; Han, K.S.; et al. Nanocomposite polymer electrolyte for rechargeable magnesium batteries. Nano Energy 2015, 12, 750-759. [CrossRef]

106. MacFarlane, D.R.; Forsyth, M.; Howlett, P.C.; Kar, M.; Passerini, S.; Pringle, J.M.; Ohno, H.; Watanabe, M.; Yan, F.; Zheng, W.; et al. Ionic liquids and their solid-state analogues as materials for energy generation and storage. Nat. Rev. Mater. 2016, 1, 15005. [CrossRef]

107. Ma, Z.; Forsyth, M.; MacFarlane, D.R.; Kar, M. Ionic liquid/tetraglyme hybrid Mg[TFSI]2 electrolytes for rechargeable Mg batteries. Green Energy Environ. 2018, 4, 146-153. [CrossRef]

108. Kar, M.; Tutusaus, O.; MacFarlane, D.R.; Mohtadi, R. Novel and versatile room temperature ionic liquids for energy storage. Energy Environ. Sci. 2018, 12, 566-571. [CrossRef]

109. Takahashi, K.; Hattori, K.; Yamazaki, T.; Takada, K.; Matsuo, M.; Orimo, S.; Maekawa, H.; Takamura, H. All-solid-state lithium battery with LiBH4 solid electrolyte. J. Power Sources 2013, 226, 61-64. [CrossRef]

110. Unemoto, A.; Ikeshoji, T.; Yasaku, S.; Matsuo, M.; Stavila, V.; Udovic, T.J.; Orimo, S.-I. Stable Interface Formation between TiS2 and LiBH4 in Bulk-Type All-Solid-State Lithium Batteries. Chem. Mater. 2015, 27, 5407-5416. [CrossRef]

111. Unemoto, A.; Nogami, G.; Tazawa, M.; Taniguchi, M.; Orimo, S. Development of 4V-Class Bulk-Type All-Solid-State Lithium Rechargeable Batteries by a Combined Use of Complex Hydride and Sulfide Electrolytes for Room Temperature Operation. Mater. Trans. 2017, 58, 1063-1068. [CrossRef]

112. Unemoto, A.; Yasaku, S.; Nogami, G.; Tazawa, M.; Taniguchi, M.; Matsuo, M.; Ikeshoji, T.; Orimo, S.-I. Development of bulk-type all-solid-state lithium-sulfur battery using LiBH4 electrolyte. Appl. Phys. Lett. 2014, 105, 083901. [CrossRef]

113. Das, S.; Ngene, P.; Norby, P.; Vegge, T.; de Jongh, P.E.; Blanchard, D. All-Solid-State Lithium-Sulfur Battery Based on a Nanoconfined LiBH4 Electrolyte. J. Electrochem. Soc. 2016, 163, A2029-A2034. [CrossRef]

114. Atsushi, U.; ChunLin, C.; Zhongchang, W.; Motoaki, M.; Tamio, I.; Shin-ichi, O. Pseudo-binary electrolyte, $\mathrm{LiBH} 4$-LiCl, for bulk-type all-solid-state lithium-sulfur battery. Nanotechnology 2015, 26, 254001.

115. Duchene, L.; Kuhnel, R.S.; Stilp, E.; Cuervo Reyes, E.; Remhof, A.; Hagemann, H.; Battaglia, C. A sTable 3 V all-solid-state sodium-ion battery based on a closo-borate electrolyte. Energy Environ. Sci. 2017, 10, 2609-2615. [CrossRef] 
116. Duchêne, L.; Kim, D.H.; Song, Y.B.; Jun, S.; Moury, R.; Remhof, A.; Hagemann, H.; Jung, Y.S.; Battaglia, C. Crystallization of closo-borate electrolytes from solution enabling infiltration into slurry-casted porous electrodes for all-solid-state batteries. Energy Storage Mater. 2019, 26, 543-549. [CrossRef]

117. Shao, Y.; Gu, M.; Li, X.; Nie, Z.; Zuo, P.; Li, G.; Liu, T.; Xiao, J.; Cheng, Y.; Wang, C.; et al. Highly Reversible Mg Insertion in Nanostructured Bi for Mg Ion Batteries. Nano Lett. 2014, 14, 255-260. [CrossRef]

118. Singh, R.; Kumari, P.; Rathore, R.K.; Shinzato, K.; Ichikawa, T.; Verma, A.S.; Saraswat, V.K.; Awasthi, K.; Jain, A.; Kumar, M. LiBH4 as solid electrolyte for Li-ion batteries with Bi2Te3 nanostructured anode. Int. J. Hydrog. Energy 2018, 43, 21709-21714. [CrossRef]

(C) 2020 by the author. Licensee MDPI, Basel, Switzerland. This article is an open access article distributed under the terms and conditions of the Creative Commons Attribution (CC BY) license (http://creativecommons.org/licenses/by/4.0/). 